Cave Exploration at Gibraltar in September, 1910.

Author(s): W. L. H. Duckworth

Source: The Journal of the Royal Anthropological Institute of Great Britain and Ireland, Vol. 41

(Jul. - Dec., 1911), pp. 350-380

Published by: Royal Anthropological Institute of Great Britain and Ireland

Stable URL: http://www.jstor.org/stable/2843179

Accessed: 07-01-2016 16:35 UTC

Your use of the JSTOR archive indicates your acceptance of the Terms \& Conditions of Use, available at http://www.jstor.org/page/ info/about/policies/terms.jsp

JSTOR is a not-for-profit service that helps scholars, researchers, and students discover, use, and build upon a wide range of content in a trusted digital archive. We use information technology and tools to increase productivity and facilitate new forms of scholarship. For more information about JSTOR, please contact support @jstor.org. 


\title{
CAVE EXPLORATION AT GIBRALTAR IN SEPTEMBER, 1910.
}

\author{
[With Plates XL-XLIII.]
}

\author{
By W. L. H. Duckworth.
}

\section{INTRODUCTION.}

THE skull brought from Gibraltar many years ago by the late Dr. George Busk, F.R.S., and presented by him to the Hunterian Museum, has been examined recently with great minuteness by Professor Sollas, F.R.S., Dr. A. Keith (Conservator of the Hunterian Museum), and Dr. G. Sera, of Naples. ${ }^{1}$ In view of the interest attached to the results of these investigations, and in consideration of the small amount of information available as to the circumstances under which the subject of these researches was discovered, I determined to visit Gibraltar in September, 1910. My reception at the hands of the naval, military, and civil authorities of Gibraltar was all that could be desired, and I have appended a list of the names of those to whom I am indebted for their interest and co-operation in my work. A brief summary of the results was published in The Gibraltar Chronicle of October 15th, 1910. In the present place, I wish to submit a more detailed account, having now worked through the material which has been deposited at the Anatomy School at the University. For this favour, the University is indebted to Major-General Perrott, C.B., lately Acting Governor of Gibraltar.

The present account falls naturally into two principal subdivisions, viz.:-A descriptive part, and a critical appendix. The purely descriptive portion will be taken first.

\section{A. Description OF THE Work.}

In visiting Gibraltar, my first object was to learn from personal observation and inquiry; so much as might be possible about the circumstances of the discovery of the now classical "Gibraltar Skull." But in addition to this quest, another enterprise was suggested to me after my arrival, viz. :- the exploration of a cave in a position difficult of access, and deemed on that account to be undisturbed by excavation either at the hands of military engineers or of archæologists. The descriptive part of this account must be subdivided therefore into sections dealing respectively with these two investigations.

\section{Forbes' Quarry and ITs Surroundings.}

It will be convenient to refer to the Gibraltar cranium already mentioned, as the Forbes' Quarry Skull, and this designation will be quite sufficient, for no other

1 For the most recent literature, $c f$. Dr. Sera, Archivio per l'Antropologia e la Etnologia, vol. xxxix, fasc. 3-4, 1909. Also an article in The Times, August 2nd, 1910. 
cranium has been obtained from that locality since the discovery of this specimen. The first point I wish to make quite clear in this connexion, is that the original minute of the "Gibraltar Society," recording the receipt of the specimen, states that it came from "Forbes' Quarry." There is no mention of Forbes' Battery, nor of "brecciated talus." Both these expressions occnr in the late Sir W. Flower's descriptive note on the specimen in the "Catalogue of the specimens in the Museum of the Royal College of Surgeons," 1879. The quarry is close to Forbes' Battery, but it is important to note that the more precise attribution of the locality of the find to the "brecciated talus" is inferential only. This point is mentioned in Dr. Busk's communication to the British Association in September, 1864, but it appears advisable to recall the fact that we have to deal with inference or presumption only in this respect. ${ }^{1}$

Forbes' Quarry still exists, and, having been worked at intervals since 1848, its boundaries have of necessity been enlarged. As stated in Sir William Flower's catalogue the quarry is " under the north front of the Rock of Gibraltar." The actual appearance of the surface exposed by the workings in this quarry can be described more clearly with the aid of the sketch (Plate XL, Fig. 1), to which reference will now be made. The face that has been worked must have had much the same character throughout, and it is quite peculiar, for the quarry lies exactly at the zone of union of the solid rock, shown in Plate XL, Fig. 1, to the right, with an extraordinary mass of consolidated débris, known as the "brecciated talus." That the skull was discovered in the brecciated talus is therefore quite possible, but I do not understand why Dr. Busk should have considered that it was derived from the superficial part. For the talus is, in fact, exposed vertically throughout a very wide extent.

As the observer stands in the quarry examining the worked face, he is presented with the talus (whether in its superficial or deeper parts), and secondly, the more solid rock, as alternative matrices to which he may refer the skull. We see that Dr.: Busk selected the former. The rock is so solid, that it would be excluded at once, were it not that just at this spot it contains a cave. The latter is indicated in Plate XL, Fig. 1, above the ladder. Its position seems to indicate that previously to the working of the quarry, its mouth must have been closed. ${ }^{2}$ One of the inspectors of police at Gibraltar can remember this cave some thirty years ago, when it was much deeper. It served then as a rendezvous for smugglers. The reduction in depth is doubtless due to the extension of the quarry whereby the cave walls are gradually being removed from its mouth inwards. It should be

1 For a full discussion of other points in the history of the Forbes' Quarry skull, Dr. Sera's masterly summary in the Archivio per l'Antropologia e la Etnologia, vol. xxxix, fasc. 3-4, 1909, should be consulted. I have nothing further to add to this aspect of the subject, beyond what I have stated in the text. The discovery of the minute in the records of the Gibraltar Society was made by Colonel Kenyon, R.E.

${ }^{2}$ A fall of many hundreds of tons of rock occurred on Christmas Day, 1910; and in consequence Forbes' Quarry is now largely filled with the débris, and the mouth of the cave blocked up. $C f$. Appendix IV. 
added that the cave is not more than 30 feet above sea level, and that it is probably the result of marine erosion at a remote epoch; and at a remote epoch also, the mouth of this cave must have been closed, until it was reopened by the quarrymen. This reopening was probably not very long ago, comparatively speaking, for I cannot make out the quarry in illustrations of this part of the Rock drawn in the eighteenth century. ${ }^{1}$

Further excavations in the locality whence the Forbes' Quarry skull was derived, must therefore be undertaken either in $(a)$ the talus or $(b)$ the cave. In the former case, the enterprise will prove of considerable magnitude, since to provide a reasonable hope of success, great quantities of the débris must be removed. A note on the character of the talus is given in the sequel, and will make this point clear. Moreover the work should not be that of excavation. This would be very dangerous on account of the nature of the talus, so that removal of the débris en masse from the surface downwards must be undertaken.

In regard to the cave, the following abstract of my notes will give an idea of the conditions obtaining there.

Tuesday, September 13th, 1910.-Cleared rubbish, etc., from the entrance of the cave, and tested the floor in various parts near the mouth. Found only a little sand above a hard stalagmite floor. Then moved to deepest part of cave (the floor inclines slightly upwards as this is approached) and cleared small boulders and a small amount of sand from a depression found there. Nothing more to be done without extensive removal of floor. Superficially, but in a sand-filled cleft in stalagmite, were found the skeleton of a rat nearly complete, and some bones of a small bird, and a rodent smaller than a rat.

Wednesday, September 14th.-Commenced removal of floor in the deepest part of the cave. Three shots were fired with black' powder. The first failed, owing to the bore-hole penetrating a layer of red sand (quite distinct from the powdery red "earth" of other caves) which mitigated the effect of the blast. The results of the other shots show that the floor consists of alternate layers of stalagmite and the red sand. The latter is of medium consistency, and the beds are rarely more than 3 inches thick, containing a few small "rolled" pebbles, and numerous pipestem-like fragments of stalactites, together with innumerable small masses of concreted limestone. The ulna of a bird of the size of a pigeon is the only representative of animal remains.

Thursday, September 15th.-A narrow cleft was noticed yesterday to lead downwards. It contained very damp clay and also sand, but no animal remains.

Friday, September 16th.-A crater was gradually excavated in the deepest part of the cave-floor. Dynamite and black powder were used, the latter proving the more effective. At a depth of 3 feet 6 inches, the sand is much coarser, though

1 At the risk of being considered tedious, I may add that in 1727, a certain Lord Forbes held a naval command at Gibraltar; the battery, called afterwards Forbes' Battery, then formed part of the "Prince's Lines." The talus then seems to have covered the whole area now laid bare in the quarry. 
pockets occur containing genuine red sand like that near Rosia, while others are filled with material resembling clay. The pebbles from the deepest san'd conglomerate are less rolled and worn than those higher up. A specimen of helix (?.H. vermiculata) was found embedded at 3 feet 6 inches from surface ( $c f$. Plate XLI, Fig. 6, No. 2). The humerus of a bird (Columba) was found at 3 feet. At 4 feet the solid limestone rock was encountered.

Saturday, September 17th.-From the crater in the deeper part of the cave, a trench was cut towards the mouth. The sand beds diminish in number and thickness, while the stalagmite remains in considerable amount. Pockets of red sand were found near the mouth of the cave.

From the foregoing account, it is apparent that the cave contains nothing save the very earliest and seemingly marine deposits covered with stalagmite. In regard to the animal remains, the rodents found in the superficial layers may have carried the bones of birds to a considerable depth by way of small fissures or clefts which would afford access to the sandy strata. The helix is seemingly a land species, but it might have been introduced by marine action.

I did not make a complete excavation of the floor, owing to lack of time and the slowness enforced upon the workmen by the hardness of the successive stalagmite strata. But the uniformity of the conditions justifies the assumption that the remaining parts of the floor will not prove very different from those already explored. In that case, it is evident that any remains of human beings must have been removed long ago from deposits in the cave which no longer exist.

Before passing to the second subdivision of this part of my work, I will add a note to what I have already written in regard to the "brecciated talus" as exposed in Forbes' Quarry.

\section{The Brecciated Talus.}

On the afternoon of September 13th two men were instructed to clear out a fissure between two great blocks of limestone in the brecciated talus. The fissure was filled with sandy rubble and masses of conglomerate. The work was slow, as much care had to be taken in undermining the large masses of stone. The only mammalian remains found were fragmentary bones of a goat (part of the humerus, Plate XL, Fig. 2) and of a rabbit. The latter bones were encrusted with limestone deposited from solution. Besides these, the only bone found was the humerus of a pigeon, and this was probably of very recent origin, for domestic pigeons are kept in the quarry by the foreman. The invertebrate remains (Plate XL, Fig. 2, Nos. 1-5) are more interesting. They comprise shelis of an' oyster (Ostraea) and a limpet (Patella) of undetermined species, covered with a deposit of limestone. In addition to these were found examples of Purpura lapillus, Arca arabica, and Videna climacterica (Plate XL, Fig. 2). Finally to these marine forms must be added 'two' species of helix' (Plate XL, Fig. 2), viz., Helix vermiculata (Plate XL,

${ }_{1}^{1}$ For the identification of these species of helix, I am indebted to Mr. J. Wilfrid Jackson, F.G.S, of Victoria University, Manchester. 
Fig. 2, No. 4), similar to that found at a depth of 3 feet 6 inches in the cave ; the second (not figured) is H. coquandi (Morelet). Both occur in North Africa as well as in Spain. The marine forms are the most interesting, and the Videna at least is not edible. Their presence may be taken as indicative of a submergence of the brecciated talus, or at least of its lower portion, since its formation.

But it should be noted that the component fragments of the talus are not rounded or "rolled." They adhere with great tenacity, and are very markedly angular. The talus as seen in Forbes' quarry is really part of a vastly greater mass of which this forms the northern limit. In its greatest extent, the talus attains a height of about 350 feet above sea-level. To the east of Forbes' Quarry the talus contains much sand with small limestone fragments. The sand is used for building purposes, and the process of "screening" shows very conveniently the various degrees of coarseness presented by it. In some parts the limestone fragments are regularly " bedded," but I find a note in my journal to the effect that the fragments are curiously little "rolled." At the highest part of the great slope (but still beneath the "North Front") some pits and trenches may be seen. The sections show little if any sand, while the numerous limestone fragments are small (rarely larger than an orange). They are not cemented together or conglomerated as in the deeper and lower parts of the slope. This is but natural, since they have been detached from the cliff most recently, so that lack of time as well as their position on the surface easily account for this contrast.

Still further east than this talus are situated the well-known Catalan Bay sand slopes. It should be noted that the sand of the latter is distinctly finer than that described in the preceding paragraph as occurring on the great slope beneath the "North Front." In the Catalan sand slopes may be seen numerous "concretions" distinct from anything met with under the "North Front." They have been formed quite recently, and indicate the first stage in the consolidation of a mass of wind-blown sand. In the same fine sand I found a small block of reddish conglomerate or breccia, but this may have fallen from above. So far as the strata underlying the Catalan sands are concerned, it will amply suffice to refer the reader to the invaluable report on the geology of the Rock of Gibraltar, made by Professors Ramsay and Geikie. ${ }^{1}$

\section{III.-The Exploration of a Cave containing Neolithic Remains. ${ }^{2}$}

In the introductory paragraph mention is made of a second cave which I was able to explore during the latter part of my visit to Gibraltar. The cave in question

1 Cf. Quarterly Journal of the Geological Society, vol. 34, 1878.

2 The classical sources of information as to the contents of the Gibraltar caves are two papers by the late Dr. G. Busk, F.R.S. One of these papers deals with the results of the famous Captain Brome, whose memory is perpetuated in the name (Genista) by which four of the caves are distinguished. The paper is to be found in the Transactions of the International Congress of Prehistoric Archoology, 3rd Session, 1868. Dr. Busk's second paper was published in the tenth volume of the Transactions of the Zoological Society, 1879. This paper deals with an older fauna than that provided by Cave $S$, and by several of the caves excavated by Captain 
is about one mile distant from the North Front, and is situated at an altitude of about 800 feet above sea-level. It opens on the Mediterranean face of the Rock, due east of St. Michael's platform and almost immediately beneath a still higher cave, designated Holyboy's Cave on the survey made by Sir Charles Warren. In my notes I refer to it as Cave $\mathrm{S}$, using this reference because I was first taken to it by Major Sewell, R.E., who had entered it many years ago.

About 30 feet below Cave $\mathrm{S}$, the great catchment area (constructed by the Admiralty) abuts on the nearly vertical rock and marks the upper limit of the underlying sand-slope now concealed by corrugated iron plates. The cave is accessible to skilled and active cragsmen only; but thanks to the kind co-operation of Mr. Wakeford of H.M. Dockyard, two of the men constantly engaged on the catchment area were placed at my disposal. These men fixed ropes and a ladder which made access to the cave perfectly easy. It is highly improbable that any human beings had entered the cave in recent years, and indeed Major Sewell considered that the floor was found exactly as he remembered it on the occasion of his earlier visit some twelve years previously. Certainly no signs of any kind of excavation were detected. The cave is remarkably dry, though this applies especially to one side and part of the deeper extremity. The mouth was partly obstructed by vegetation, the Palmetto and a genista-like shrub. A small collection of recent land-mollusca was made in this part of the cave. No bats were seen at any time during the excavation, nor were flies noticed. In a similar cave under the North Front visited by me a few days earlier, swarms of these Diptera were present, and would render any prolonged sojourn in such a cave quite uncomfortable. The general form of Cave $\mathrm{S}$ will be best understood by reference to the accompanying plan and section (Figs. 1 and 2), which are drawn approximately to scale. It will be noted that the main axis of the cave slopes downwards towards the mouth. High above sea-level though this cave is situated, its formation might be ascribed to marine influences. It has practically none of the characters of a fissurecave. Its existence thus bears witness to a submergence of the Rock to at least this extent, viz., 800 feet. This is by no means the only evidence of such submergence. Raised beaches and fossil or semi-fossil marine mollusca ${ }^{1}$ have been recorded at 700 feet above the present sea-level. So far as is known, this great submergence must have occurred since the formation of what is called the "Great Agglomerate" of Buena Vista and its neighbourhood on the western side of the

Brome. In the second volume of the Collected Memoirs of the late Dr. Falconer, yet another and very useful paper will be found, written conjointly by that authority and Dr. Busk. I refrain here from detailed references to earlier works, such as those of Cuvier and Hunter, on the fossil mammalia of the Rock. For comparative purposes I find the Reliquice Aquitanica of Lartet and Christy invaluable. The volume by Rivière entitled L'Antiquité de l'Homme dans les Alpes maritimes, the Collected Memoirs of Dr. Falconer, and Mr. Peet's book on the Stone and Bronze Ages in Italy, are also of prime importance in this respect.

1 The scantiness of fossils in the actual Rock itself has long been noted. Yet Mr. Frere pointed out to me such a fossil (apparently a nautilus) in a block of Gibraltar limestone forming part of the doorway of the Port and Treasury Office at the Grand Casemates Gate. 
Rock. ${ }^{1}$ Moreover, there is evidence that the filling of fissures in that agglomerate with bone-breccia containing the Pleistocene fauna had commenced before this submergence was initiated.2

A third possibility exists, viz., that this cave has been formed simply as a result of blocks of limestone becoming detached at the joints which traverse the

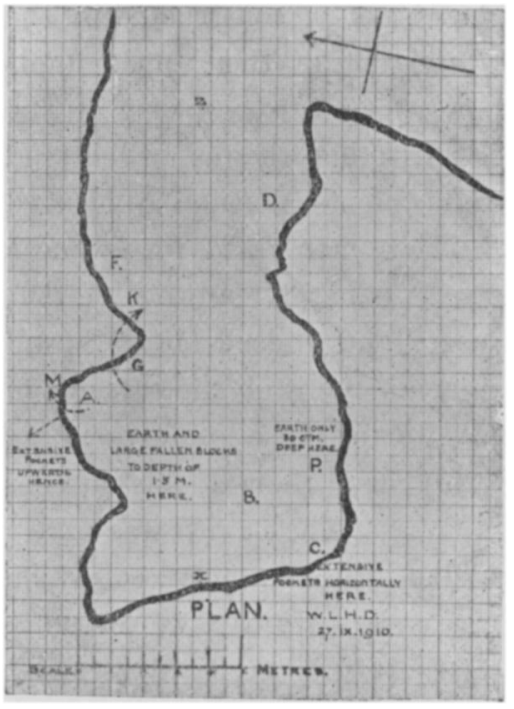

Fig. 1. PLAN OF BEweli's CAVE (CAVE S), gibraltar. rock in every part. This process of detachment is still going on in the cave. Should this view be adopted, no need exists for an appeal to former submergence of the Rock, to the extent suggested in the preceding paragraph.

For descriptive purposes, the cave may be conveniently divided into two portions. First, an outer part or vestibule, with a floor composed of solid rock covered with a minimum of sand and encumbered with brushwood. This part was not capable of excavation. Secondly, the cave proper, with an earth-covered floor which was subsequently excavated. A line drawn across the plan from $K$ (Fig. 1) in a southerly direction will divide these two parts from each other. The first striking feature on entering the cave is the peculiar nature of the earth covering the denser parts of the floor. This earth resembles nothing so much as snuff of a rich brown colour, and it is extraordinarily fine and tlour-like in consistence. A fair proportion must be vegetable mould, and it is very likely that the guano of

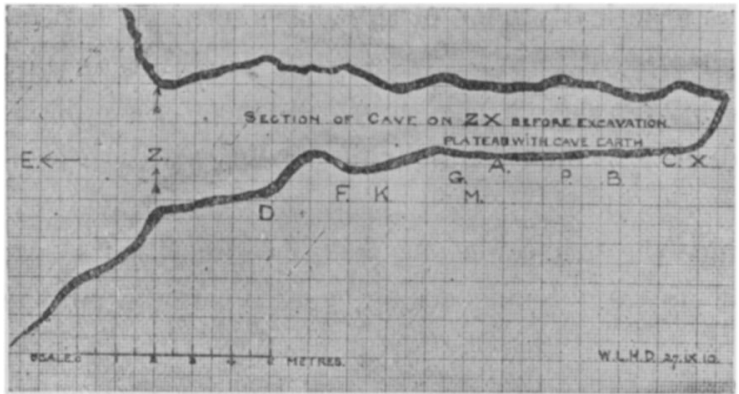

HIG. 2. SECTION OF BEWRLL's CAVE (CAVR 8) ON XZ OF PLAN (FIG. 1). bats enters into its composition, although as noted above, the cave is not apparently inhabited by those animals at present. No doubt cave-earth of the usual kind is mixed with this brown powder, but the red tint of the cave-earth proper is masked by the darker colour of the vegetable mould. Deeper down, the character changes and in certain pockets, notably near A in the plan (Fig. 1) and along the northern wall of the cave, a coarser but still powdery earth of a light brown tint replaced the superficial deposit. But, so far

1 Ramsay and Geikie, op. cit., p. 525.

$2 "$ " " " " p. 531 . 
as the excavation went, it may be stated that fine earth of one variety or another was found covering and surrounding on all sides the other contents of the floor to a depth of 4 feet 6 inches. If there be a stalagmite floor beneath this, it was not reached in the excavation. The remarkable dryness of the cave in the greater part of its extent has been alluded to, and this consideration throws some doubt on the existence of a stalagmite floor, although this point cannot yet be regarded as proven.

The second point attracting attention was a collection of small angular limestone fragments partially embedded in the brown earth of the floor, but quite easily discernible before any interference with the floor was undertaken. They formed a roughly circular patch measuring about two feet in diameter ( $c f . \mathrm{B}$ in the plan, Fig. 1). Major Sewell recognised this as a common feature of the local caves. The appearance is strongly suggestive of a Neolithic workshop, the fragments representing waste splinters and chips. But as already remarked, the material is limestone, and though Professor Rivière has described implements of limestone from the Mentone caves ${ }^{1}$ yet an application cannot be made to the present case without some investigation of the circumstances. Now it is clear that if these chips of stone are of the nature of "wasters," like those found in the case of flint manufactories, they should not now lie on the surface, unless the latter had been recently disturbed, and of this, no other evidence is fortheoming. A careful examination of the fragments is not productive of any encouragement of this explanation, nor is further evidence of their artificial origin provided thereby. I hold the view that the real nature of these fragments is that they are not artefacts, but that they represent the remains of a limestone block which fell from the caveroof and then became disintegrated where it fell. This is not a mere hypothesis, for such disintegration has been described in other instances. ${ }^{2}$ And in Cave $\mathrm{S}$ there is abundant evidence both that blocks fall from the roof and also that they may thereafter split up into much smaller fragments than those now under consideration. Finally, as will appear in the sequel, such undoubted implements as do occur are not of limestone, but of some other material.

A third point to be noticed before a description of the excavation is commenced, consists in the occurrence of numerous "pockets" and clefts, especially in the regions marked respectively $A$ and $C$ in the plan (Fig. 1). In the case of the part marked A, a fissure large enough to admit a man ran upwards and then turned somewhat spirally outwards from the cave. In this fissure some stalactites were found, but otherwise such formations were conspicuous by their absence. The fissure in question was filled with earth (containing a few bones) in its lower part only. The upper part was eropty and freely accessible. Doubtless it owes its existence to the falling out of some blocks between joints in the solid rock; such rocks were afterwards found in the floor of the cave near this point.

Excavation was commenced (on Thursday, September 22nd, 1910), in the first

1 Cf. Peet. The Stone and Bronze Ages in Italy, p. 39:

${ }^{2}$ Cf. Lyell, Principles of Geology, vol. ii, p. 227, 1833. 
instance, at two points, viz., in the bays marked $\mathrm{A}$ and $\mathrm{C}$ on the plan (Fig. 1), and the adjoining pockets were carefully cleared out. Subsequently the earth was removed from the more central parts of the floor (towards B in the plan), and finally at $\mathrm{P}$. It was evident that $\mathrm{A}$ is the deepest part of the cave and that the floor slopes down to this region from the other parts indicated in the plan, with the exception of $\mathrm{G}$. In the latter situation a tunnel nearly large enough to enable a man to pass was driven through the earth beneath an overhanging prominence towards the point marked $K$ in the plan. In the latter situation the earthy strata are shallow again, and near $\mathrm{F}$ ( $c f$. plan) the brushwood of the outer part often encumbers the outer part of the cave. Near B and P little else than the cave-earth was found.

Upon removing the most superficial portion of the earth, bones were at once obtained, among the earliest being the left tibia of an adult man. It became evident that unless great care were taken bones would be fractured by the workmen as they stood in the soft mould; and so far as was possible, precautions were taken to guard against this. As the bones and other objects were brought to light they were collected in baskets or upon large sheets of paper, bearing an indication of the part of the floor that had yielded them. The bones from the pockets at $\mathrm{C}$ were easily identified afterwards for they were moist, whereas near A and towards B the bones were very dry.

Without entering into further details concerning the nature of the floor of the cave, a list of the excavated objects will be given in the next place. The list falls into subdivisions as indicated in the statement following:-

Classification of objects obtained from Cave S.

\section{Human Artefacts.-}

Pottery.

Stone implements.

Other stone objects.

Shell armlet.

Perforated Cyproea.

Charcoal.

Incinerated bone.

Burnt stones.

Bone implements.

Bone splinters.

Broken shells of Purpura hoemastoma.

\section{Mammalian Fauna.-}

$\begin{array}{llll}\text { Primates } & \ldots & \ldots & \text { Homo. } \\ \text { Carnivora } & \ldots & \ldots & \text { Felis lynx. }\end{array}$




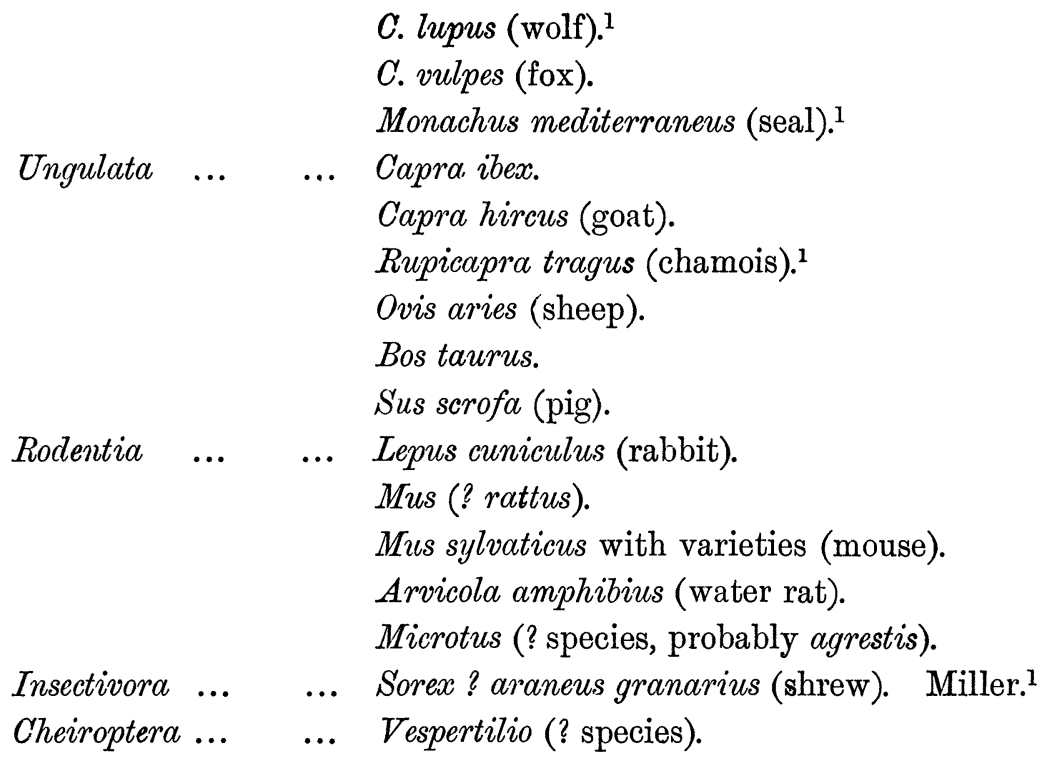

III. Aves.-

Vultur fulvus (vulture, not eagle, as previously stated).

Corvus or Pyrrhocorax (chough).

Columba livia (rockdove).

Turdus (? species ; fieldfare or thrush).

Falco tinnunculus (kestrel).

Tetrao francolinus (francolin). ${ }^{1}$

Sula alba (gannet). ${ }^{1}$

Phalacrocorax carbo (cormorant). ${ }^{1}$

Fratercula arctica (puffin). ${ }^{1}$

IV. Reptilia.-

Monitor (? niloticus). ${ }^{1}$

Testudo (? species; tortoise).

Gecko mauritanica (gecko). ${ }^{1}$

V. Pisces.-

Thynnus thynnus (tunny).

Pagrus (? species ; pagre).

VI. Invertebrata.-

A. Mollusca... $\quad$.. Purpura homastoma.

Purpura lapillus.

Trochus tessellatus.

Cardium rusticum.

1 Not previously recorded as occurring in the cave fauna of the Rock 


$\begin{array}{ll} & \text { Cardium (? species). } \\ & \text { Solen vagina. } \\ \text { Patella (? species). } & \\ \text { Pecten marinus. } \\ \text { Mytilus edulis. } \\ \text { Triton nodiferus. } \\ \text { Cyproea pyrum (cf. I, supra). } \\ \text { Cassis sulcosa. } \\ \text { Helix. } \\ \text { B. Echinodermata ... Sphorechinus granularis. }\end{array}$

A few remarks will be offered on each of these objects, taken in the order of their classification.

\section{Human artefacts.}

Pottery.-The pottery consists of some twenty sherds of varying size and thickness derived from rounded vessels. The sherds are red or black in colour. Many are of such poor quality that the material crumbles between the fingers. There is no evidence of ornamentation, though some of the sherds are polished and many show signs of exposure to a fire. Having had the opportunity of submitting these objects to A. J. Wace, Esq., Fellow of Pembroke College, I am fortunately able to give his opinion, viz., that all the sherds are of a very primitive type, corresponding to the "proto-pottery" of other parts of the Mediterranean area. The clay is of very poor quality, but has nevertheless been baked. The ware is hand-made and hand-polished.

I may add that this ware is of the most primitive type so far discovered in the caves of the Rock. The sherds found by Brome were marked with a sort of primitive pattern or design.

Stone implements. - The mineralogical aspect may be considered first. Through the kindness of W. G. Fearnsides, Esq., F.G.S., Fellow of Sidney Sussex College, I am able to make the following statement in this connection :-

Nos. 2, 3, 4 are quartzite ( $c f$. Plate XLI, Fig. 1).

No. 5 is flint.

Nos. $6,7,8$ and 9 are of chert.

Nos. 12 to 17 inclusive are most probably of silicified sandstone (cf. Plate XLI, Figs. 3 and 7 ).

No. 19 is a very delicate blade of flint ( $c f$. Plate XL, Fig. 4, No. 2).

Coming next to the archæological characters of the stone implements, I am enabled, through the kindness of Baron A. von Hügel, to report as follows :-

In general, the implements resemble those found in caves elsewhere. No. 2 is the most characteristic in this respect. In particular, one (No. 7) (cf. Plate XLI, Fig. 2) resembles part of an implement found in Kent's Cavern and figured by Evans (op. cit., p. 498, Fig. 391), by whom it is compared to the type of Solutré 
(Palæolithic). No. 15 ( $c f$. Plate XLI, Fig. 2) is also a scraper of a type found in Kent's Cavern (cf. Evans, op. cit., Fig. 397). No. 13 (cf. Plate XLI, Fig. 2) is a scraper. When complete the form of this implement was probably triangular (cf. Evans, op. cit., Fig. 212).

In addition to these remarks by Baron von Hügel, I venture to make the criticisms following. Some of the implements appear distinctly Palæolithic. No. 2 (a quartzite implement) approaches the Mousterian type, and much resembles some quartzite implements described by me in the Quarterly Journal of the Geological Society (vol. li, 1895). These were obtained from a cave in the Creswell Crags, Derbyshire, associated with bones of rhinoceros, bear, hyena, and reindeer.

Dr. Sturge has kindly examined the implements from Cave S, and he considers that Nos. 2, 7, 13, are of Mousterian type, while No. 15 is either Mousterian or early Aurignacian in type.

Lastly, I find these implements from Gibraltar agree closely with some of those obtained in the Cro-magnon Carern at Les Eyzies (cf. especially Reliquice Aquitanica, Pl. XX, Figs. 2, 6). The very delicate flake, No. 19, bears a bulb of percussion on its unworked surface, and its slenderness indicates that the maker had attained a fair degree of skill in his art. But the absence of any example of the great massive flints of the St. Acheul and Chelles types is to be remarked.

Stone objects other than implements.-Turning to the remaining stone objects, we notice that the large flake, No. 1 ( $c f$. Plate XLI, Fig. 3), is considered by Mr. Fearnsides to consist of a metamorphic rock allied to quartzite. It is remarkably like a quartzite implement from the Robin Hood Cave in Derbyshire figured by Evans (op. cit., Fig. 413A, p. 522). No. 10 ( $f f$. Plate XLI, Fig. 3) is a rounded mass resembling the "hammerstones" described by Evans (op. cit., Fig. 402, p. 503). No. 11 ( $c f$. Plate XLI, Fig. 1) is a cuboidal block of very heavy hæmatite. It leaves a faint trace on unglazed porcelain, but is too hard to have served as a source of cosmetic pigment. It is possible that this block was used as a "sling stone," for which purpose its great density is well adapted. No. 12 ( $c f$. Plate XLI, Fig. 3) is a mass of silicified sandstone, doubtless the core whence chips similar to Nos. 13 to 17 inclusive were derived.

To sum up the foregoing description, I would say that Nos. 2 (quartzite), 7 (chert), 13, 15 (silicified sandstone closely resembling chert), and 19 (flint) are the most striking specimens. The general indication is that the art of fabricating such objects had reached a fair though not a very high standard, and although some of the implements are of Palæolithic, i.e., Mousterian form, they may be attributed to a low stage of Neolithic culture. The irregularity of their distribution makes the task of subdividing them according to their position an impossible one. The absence of polished implements is the more noteworthy inasmuch as such objects were obtained in other caves at Gibraltar, and in surroundings closely resembling those considered here. The materials are variable, and some, e.g., the hæmatite, must have been brought from a considerable distance.

Shell armlet.-A portion of a shell armlet ( $\bullet f$. Plate XL, Figs. 4 and 5 ) exactly 
resembles a fragment found by Captain Brome in the Genista Cave, No. 1, and figured by Busk (Transactions of the International Congress, etc., Pl. VIII, Fig. 1). Mr. Wace tells me that such armlets occur in Neolithic sites in the Egean area, and also in Egypt.

Perforated shell.-A single example of a Mediterranean cowrie, Cyproea pyrum, was found. It is remarkable on account of an artificial perforation at one end ( $c f$. Plate XL, Figs. 4 and 5). This is the only object found that represents an article used for personal decoration. We may further note that perforated shells of Cyproea pyrum occurred at Cro-magnon, as well as in the Mentone Caves of Baoussé-Roussé. ( $C f$. Evans in Rel. Aq., p. 179, for Cro-magnon, where the shell was in the fossil state; and Rivière, op. cit., Pl. XXI.)

Charred or burnt objects.-Masses of charcoal occurred throughout the thickness of the cave-earth, but nowhere in great abundance. In addition to this, several charred fragments of bones of goats and one vertebra of a tunny (fish) were found, as well as a few blackened splinters of limestone.

Bone implements.-Such implements occur in other caves in the Rock, but in the present instance, only three doubtful examples can be mentioned. These are metatarsal bones of a young goat, and their rounded surface appears to have been modified by attrition, as though they had been used for polishing or rubbing. However this may be, their form is now prismatic and not cylindrical or oval in section. I have found no record of comparable examples elsewhere.

Bone splinters. - As in all excavations, splinters of bone are extremely numerous. But they own very different origins. A few are doubtless due to the picks and other implements used by the workmen in their excavation. Others are referable to the action of fire, and are easily recognisable by their partially incinerated condition. Some may be due to atmospheric action, for I find at least one beautiful example (metatarsal bone of goat) of a bone split longitudinally, the two fragments being kept close together by a mass of chalky limestone which fills the narrow cavity completely and protrudes on each side along the lines of fracture.

It is to be noticed that whereas by far the greater number of bones of all kinds are referable to the goat (C. hircus), in only a single instance was a complete and perfect bone of that animal obtained. Many fragments bear the marks of teeth, naturally those of the carnivorous animals associated with these ungulata. But many other fragments seem to have been split by human agency.

In vain I have sought for such bone splinters as might be described as "implements." Equally fruitless has been my search for any carving, engraving or perforation of the bones.

Shell fragments.-The list of specimens (q.v.) shows that numerous shells of mollusca occur. Naturally many of these are fragmentary. In the present connection, I would draw attention to the fact that the examples of Purpura are few in number, not more than about half a dozen in all. Of these specimens three ( $f f$. Plate XL, Fig. 3) present a remarkable appearance. The apex of the shell has 
been broken in each case, but in addition, a large aperture has been made lower down and opposite the mouth of the shell. All three shells agree in this. Moreover they are in accord herein with the Purpura shells obtained in such numbers at Sidon from the ancient refuse heaps near that port. The Rev. A. H. Cooke believes that the peculiar fracture indicates that the mollusc was used for the preparation of its distinctive product, the Tyrian "purple." This ingenious suggestion is founded upon a knowledge of the anatomy of Purpura, and therefore I have ventured to mention these three specimens in this connection.

\section{Mammalian fauna.}

Man.-The human bones (Plate XLIII, Fig. 3) are referable to a single individual, evidently an adult male of powerful physique, and of stature approximating to $1650 \mathrm{~mm}$. (5 feet 5 inches). (From Pearson's abacus, using the length of the right tibia, cf. Pearson, Phil. Trans. Roy. Society, vol. xcii, A, p. 169.)

The bones are heavy and must still contain a considerable proportion of organic matter. Their appearance in this respect need not contra-indicate a very considerable antiquity. They conform precisely to the description given by Busk (cf. Transactions of the International Congress, p. 147) of human bones found in the Judges' cave (Glen Rocky) associated with bones of an ibex.

The actual specimens found comprise those in the following list ( $c f$. Plate XLIII, Fig. 3) :-

(a) Vertebræ. C. 7, Th 1, 3, 5, 10,12, $L$ 1, 2,3, and part of the auricular facet of the right side of the sacrum.

(b) Ribs. No. 1 of the right side. Eleven other fragments principally of the larger ribs of each side.

(c) Part of the right scapula and acromial part of the left clavicle.

(d) Right scaphoid bone of carpus. All metacarpals (save No. 1) of right hand, and metacarpal No. 4 of left hand. A few phalanges of the fingers.

(e) A large portion of the right innominate bone with three fragments of the same or of its fellow of the left side.

(f) Right fibula, both patellæ, tibiæ, and astragali.

(g) Right navicular bone of foot, left entocuneiform bone. All the metatarsal bones (right and left) except No. 4 of the right foot. A few phalanges of the toes.

In the first instance, the wide dispersal of these bones in the cave earth must be mentioned. No two bones were in their natural relation; touching the left clavicle was a bone of the left foot. The tibiæ were about 6 feet distant from each other. Some bones were deeply embedded beneath overlapping rocks. A phalanx 
bone of a finger was found at the spot marked $K$, where few other bones occurred. No fragment of skull, ${ }^{1}$ arm bones or thigh bones could be found.

In spite of this dispersal, the characters of the bones enable me to refer them confidently to one and the same skeleton. Some of the inferences to be drawn from their study will now be set out in detail, commencing with the bones of greatest importance for this purpose.

Os innominatum (Plate XLIII, Fig. 3). - The sex of the individual is clearly shown by this bone to be male. No features of inferiority in the form of the bone can be detected. The consolidation of the bone indicates the full maturity of the skeleton.

Tibice.-The most striking features are the massiveness and the "inflected" form of these bones (Plate XLIII, Figs. 1 and 2). These characters recall the tibia of the Palæolithic cave-man of Spy in Belgium. But a more careful examination convinces me that this similarity cannot be pressed. For in another and very important character, the resemblance is not maintained. I am therefore obliged to qualify the statement on this subject as given in my preliminary report ( $c f$. The Gibraltar Chronicle, October 15th, 1910), and to remark that the similarity is noticed in two features only.

The divergent character in question is that known as platycnemia, or flattening (in the transverse direction) of the tibial shaft. This character is very pronounced in the human tibiæ from Cave S ( $c f$. Plate XLII, Fig. 2, GIB.)

The appearance may be due to one or more of several factors, and the specimens thus characterised can be classified according to the factor which has been most influential.

In the present instance, that factor is an osseous ridge, known as the ridge of the posterior tibial muscle ( $M$. tibialis posticus), which has been drawn out in these tibiæ, so as to project very markedly from the hinder service of the shaft. In other examples, the ridge of the soleal muscle (also posterior in situation) is prominent, and in others again, neither of the above ridges, but an anterior ridge may be unduly exuberant in growth.

It is interesting to note that the ancient cave tibiæe from Perthi-Cwareu (described by Busk and Boyd Dawkins, cf. Boyd Dawkins, Cave Hunting, p. 173) are in the latter category. Hypertrophy of the soleal ridge is well shown in a modern tibia from the Cambridge Dissecting Room. A section of this tibia is shown in Plate XLII, Fig. 2. Finally the tibiæ from Cave S are very distinctly associated, not with the Spy tibia, but with the tibia of the skeleton found at Cromagnon in the Dordogne district. And it is important to note that other tibiæ from the Gibraltar caves described by Busk ( $c f$. Boyd Dawkins, op. cit., p. 175) agree with those now under consideration.

The foregoing characters can be recorded in a numerical form by the employ-

${ }^{1} C f$. Lyell's remarks (Antiquity of Man, p. 63) on the apparently capricious preservation of different parts of the human skeleton, as exemplified by the remains found in the Belgian caves explored by Schmerling. 
ment of an index expressive of the ratio between the two axes (viz., the transverse and the antero-posterior) of the tibial shaft, measured at the level at which the soleal line merges into the internal ridge of the bone. The values of these indices, together with the other measurements of the bones, are given in the accompanying table.

\section{Tibice from Cave S, Gibraltar.}

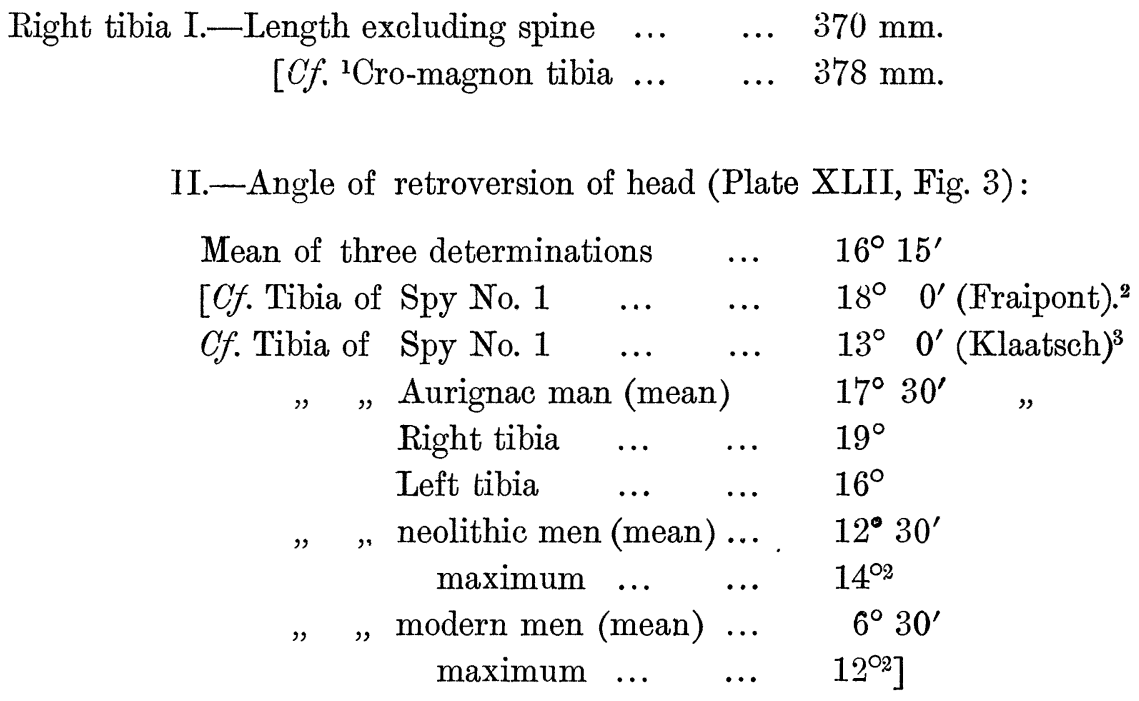

III.-Index of platycnemia (Plate XLII, Fig. 2):

Mean of right (58.75) and left (60) tibiæ $59 \cdot 3$

$\left[C f .{ }^{1}\right.$ Cro-magnon tibia... $\quad \ldots \quad \ldots \quad 61 \cdot 0$

${ }^{3}$ Spy No. 1, tibia $\ldots \quad \ldots \quad \ldots \quad \ldots \quad 70 \cdot 7$

${ }^{3}$ Tibia from Moustier $\quad \ldots \quad \ldots \quad 87 \cdot 1$

${ }^{4}$ Modern tibiæ (French) $\left.\quad \ldots \quad \ldots \quad 88 \cdot 0\right]$

Returning to the subject of the "inflected" character of these tibiæ (Plate XLII, Fig. 3) it will be seen from the angular measurements given in the

1 From measurements of ${ }_{1}^{1}$ the cast of the bone, W. H. L. D. There is au crious uncertainty about the exact origin of this cast. It accompanies the casts of the cranium and femur of the "old man" of Cro-magnon in the Cambridge Museum. But I find from Broca's report in the Reliquice Aquitanica that the tibia of the "old man" was imperfect (op. cit., p.103, and Plate cvi). However, the measurements of the thickness of the shaft agree in the cast with the description in the work cited. On the other hand, the length of the cast agrees with the dimensions of the Madelaine tibia recorded by Hamy on p. 270 of the Reliquice Aquitanicae, and figured in Plate CX of that work.

2 Fraipont, Revue d'Anthropologie, 1887.

3 Klaatsch, Zeitschr. für Ethnologie, vol. 42, p. 553, 1910.

${ }^{4}$ Manouvrier, Bull. de la Soc. d'Anthr. de Paris, Tome X, 1897.

5 Otherwise called the " recurved" or " retroverted" character.

VOL. XLI. 
table that this feature distinguishes them from those of modern men, while allying them with those of prehistoric human beings.

A careful investigation of the upper articular surface of these tibiæ does not provide me with any further occasion for comment. But at the opposite end of the bone (for the right bone only is sufficiently complete to yield this information) a character of inferiority is very evident (Plate XLII, Fig. 4). In this situation the lower articular surface sends a tongue-like projection upwards on to the anterior aspect of the bone. Such a localised prolongation of the articular surface is known to characterise the skeletons of men who habitually adopt the "squatting" attitude. Accompanying this, a corresponding extension (or sometimes an islet of articular surface) is found on the adjacent aspect of the astragalus; and both astragali are thus marked in the present instance. (This subject has been investigated by Sir Havelock Charles, and by Professor Arthur Thomson.)

In passing to other bones from the tibiæ, it is advisable to note that in these very distinctive elements of the skeleton of the lower limb, the human individual from Cave $\mathrm{S}$ is found to resemble other prehistoric examples in three definite characters, while agreeing in yet another respect with the more lowly varieties of existing mankind. This is the most important outcome of the examination of these human remains.

Fibula.-This is a stout bone of the right lower limb, measuring $357 \mathrm{~mm}$. in length. Beyond deep channelling for the peroneal muscles, it presents no special features of note. Herein it agrees with the fibula of skeleton "No. 1," from Cromagnon (cf. Broca in Reliquice Aquitanicae, p. 110, and Plate C vi in that work). The rarity with which the fibula is preserved, as compared with the tibia in the Gibraltar caves, has been noted by Busk (cf. Transactions International Congress, p. 160).

Astragalus. - Both were found. The most important character is the articular facet on the outer portion of the upper surface of the "neck" of the bone (Plate XLII, Fig. 1). To the inside of the "neck," the non-articular isthmus between the articular areas of the head and upper surface respectively) is remarkably narrow. Beneath this isthmus, the articular area of the head is continued unusually far backwards. The fibular facet is very extensive, as in the skèletons from La Chapelle and La Quina.

Navicular bone of the Tarsus.-The right bone only was found. The only features demanding notice are the almost quadrate outline of the astragalar facet, and the extension of the anterior articular area outwards to beyond the ectocuneiform surface, so as to provide for articulation with the cuboid.

Entocuneiform.- $(C f$. Plate XLI, Fig. 5, No. 1). Only the left bone was found. The prolongation of the metatarsal facet inwards is hardly beyond the range of normal variation in modern bones. The dorsi-ventral axis of this facet is very nearly rectilinear, not curvilinear, with an internal convexity as in the case of the lowly human races. The illustration (Plate XLI, Fig. 5) shows this bone (No. 1) in association with the corresponding bone from the skeletons of an aboriginal native of Australia (No. 2) and a chimpanzee (No. 3) respectively. 
Metatarsals.-Only the first metatarsal will be described. The bones from both feet were found. The proximal end (in each bone) bears a facet concave from side to side but not more so than in most modern instances. In neither bone does a facet for the second metatarsal appear. The left bone has a remarkable perforation in the shaft at its outer side. The appearance seems to point to an artificial origin, and a vascular foramen of such large size was not seen in any of some twenty-five modern bones examined for the purpose of comparison. On the whole, however, in consideration of the fact that a vascular foramen of small size normally occurs here, it is judged that the present large aperture is of that nature and is not artificial.

Patella.-Both bones were found. They present no characters of inferiority. The inferior tubercle is well marked and gives each bone a somewhat triangular contour.

Ribs.-Some of the fragments are remarkably deep, one (from the right side) measuring as much as $22 \mathrm{~mm}$. This character is in correlation with the general massiveness of all the bones.

Clavicle.-Judging from what' remains of the left clavicle, this bone was of slight proportions in comparison with the rest of the skeleton. The chief interest of this observation lies in the fact that a similar disparity characterises the palæolithic men of Krapina in Croatia. (It may be added that among the great anthropoid apes, the Gorilla is similarly distinguished from the Orang-utan, which has relatively large clavicles.)

The remaining bones ( $c f$. List) call for no special comment.

Carnivora (Felix lynx).-This form is represented by the left half of an adult mandible.

Canis lupus.-The wolf has not been recorded previously as occurring in the cave fauna of the Rock. ${ }^{1}$ It is here represented by two metatarsal bones and part of a humerus. All these are adult and were found 'widely separated.

Canis vulpes.-This identification depends on a single vertebra from a young individual. It is not impossible that the bone may be that of a young wolf.

Monachus mediterraneus (the hooded seal).-This animal has not been identified previously in the Gibraltar cave fauna. Here it is represented by parts of two individuals, one adult and the other immature. Its presence in a cave 800 feet above sea-level can be accounted for only on the supposition that man (or a bird of prey) introduced the bones. The rarity of remains of seals in association with prehistoric human remains is somewhat surprising. ( Up to 1900, only one instance seems to have been recorded in Europe. But seals are depicted on some of the prehistoric carved bones.) I may add that the determination of the particular seal found in Cave $S$ is undoubted, since it possesses but two upper incisor teeth on each side, differing herein from its "Arctic" congeners. Among

1 Boyd Dawkins (op. eit., p. 372) is apparently mistaken in his statement regarding this animal. At any rate, no confirmation can be gleaned from Dr. Busk's paper in the Transactions of the Zoological Society, vol. x. Indeed, the absence of bones of the wolf is there commented upon. 
the fragments found, a left upper premaxilla fortunately came to light, thus clinching the diagnosis.

Ungulata (Capra ibex).-Two individuals are represented. The determination rests upon the evidence of the limb bones (cf. Plate XLIII, Figs. 4 and $\tilde{5})$. I would remark again that the larger individual is further noteworthy, inasmuch as the bones seemed to be disposed to some extent in a natural sequence or order. They were covered by about 3 feet of cave-earth.

Capra hircus.-The goat occurred in very great numbers, as usual in the caves of the Rock. The smaller size of the bones ( $c f$. Plate XLIII, Figs. 4, 5) distinguishes them from those of the larger ibex. It is not too much to say that hardly a single bone of this animal (goat) was obtained unbroken. A majority seem to be immature, the epiphyses having become separated from the long bones. Among the immature examples are some of very small size, and to these remains it is really only possible to assign the general term "capra." In sorting the bones, I have regarded nearly all such indeterminate specimens as belonging to these species. A few seem to be more like bones of sheep.

Rupicapra tragus.-The chamois is now recorded for the first time. But the determination rests on the evidence of a single bone ( $c f$. Plate XLIII, Fig. 5, No. 1). This specimen, a metatarsal bone, gave much trouble in identification, the choice lying between the sheep (Ovis aries) and the chamois. Had I only possessed access to the bones of modern "domestic" sheep, I should have unhesitatingly labelled the present specimen as "chamois." But the ovine species vary considerably, and a sheep from the peat of the fens is very different from a modern Shropshire ewe. However, after careful comparison, I am confident that the bone in question resembles the corresponding bone of the chamois more closely than it does those of the sheep at my disposal. The point is not unimportant, for should the former existence of the chamois on the Rock be established, an indication of somewhat colder conditions is hereby provided.

Ovis aries.- Represented by a few bones of immature individuals, not certainly distinguishable from goats.

Bos taurus.-As recorded by Busk, individual animals of this species are found of very varying dimensions. In the present instance the bones are few and fragmentary. At least one specimen looks quite recent, and it may have been introduced by a raptorial bird.

Sus scrofa.-A few bones, including the left half of an immature mandible, were found: they denote animals of small size, as judged by that of the modern boar, or domestic swine, and they agree in this respect with the specimens described by Busk.

With the exception of the bones of Bos taurus, all the foregoing specimens seem to have been long embedded in the cave-earth, which has stained them deeply. The bones of the larger ibex are spotted in a manner exactly reproducing the appearance of the ibex bones from Gibraltar, figured by Busk (Transactions of the Zool. Soc., vol. x, Plate XXV) and assigned by that writer to the Pleistocene epoch. 
Rodentia (Lepus cuniculus).-The rabbit is represented more numerously than any other animal, not even excepting the goat. No bones can be referred to the hare (L. timidus).

Mus sp.? rattus.-Identified by the form of the teeth and of the os innominatum.

Mus sylvaticus.-Remains of a mouse were plentiful, and are distinguished by the dental characters from their larger congeners. But the mandibles referred to the sylvan mouse vary in size. One example especially (Plate XLI, Fig. 4, No. 6) is rather larger than the rest. The cheek teeth together measure $4 \mathrm{~mm}$. in length. The "anterior accessory cusp" of the first cheek tooth is but feebly indicated. In the foregoing respects, this mandible differs from those of $M$. sylvaticus, and agrees with an allied species, at first called by Mr. E. T. Newton $M$. abbotti, and later ( $c f$. Newton, Proc. Zool. Soc., 1899, p. 381) Mus lewisi. It occurred in a chalk fissure at Ightham in Kent ( $c f$. Newton, Quart. Journ. Geol. Soc., vol. 1, 1894, p. 195). I must lay upon Mr. Newton's shoulders the responsibility for this species, but the observations mentioned above" may be held to provide additional confirmation of the differences upon which its segregation is based. It must be added that Mr. Hinton does not recognise a distinct species in this form.

Arvicola amphibius. - No teeth were discovered: the determination rests on the characters of certain ossa innominata.

Arvicola or Microtus (? species).-A second species of Arvicola, probably the field-vole, is represented by numerous ossa innominata. (Plate XLI, Fig. 4, No. 8.)

Insectivora (Sorex).-Two or three mandibles of the shrew were found (Plate XLI, Fig. 4, No. 7). This seems to be the second record of the occurrence of a shrew in Spain ( $f f$. Miller, Magazine of Natural History, November, 1910, p. 458).

Cheiroptera.-Only one bone (a humerus) of a bat has been recognised. The bone is that of a small animal (Plate XLI, Fig. 4, No. 2).

\section{Aves.}

The corvine remains almost certainly comprise those of the chough (Pyrrhocorax); they are abundant, as at Les Eyzies (Cro-magnon), and elsewhere in cave deposits.

The francolin. The occurrence of this bird (which is allied to the partridge) is interesting, for it has long been extinct in Spain, although still inhabiting Cyprus and the countries eastward of that island. (Cf. Newton, Dictionary of Birds, Part I, art. "Francolin," and Florio. ${ }^{1}$ )

The cormorant is represented by a single fragment, the hinder part of the skull. Two bones only of the gannet were found, but are absolutely distinctive.

The puffin. The bones may possibly be those of the shearwater (Puffinus

1 "Francolina, a daintie bird called a goodwit. Some also take it for a moore hen, others for a feasant pout." Florio's Italian Dictionary, 1598. 
major), but my comparative material does not enable me to pronounce definitely on this point. The shearwater occurs abundantly in the caves of Corsica Iydekker, P.Z.S., 1891, p. 467).

\section{Reptilia.}

A large reptilian jaw accords better in its characters with Monitor niloticus than any other form at my disposal for comparative purposes. But this reptile has not been previously recorded on the Rock, so far as I know.

The tortoise, probably Testudo graeca, is represented by a humerus only (Plate XLI, Fig. 4, No. 1).

The gecko is found at the present time near Algeciras, but I do not know of a previous record of its presence on the Rock.

\section{Pisces.}

These require no special comment, both forms existing at present in the neighbouring sea.

\section{Invertebrata.}

A. Mollusca.-All the forms discovered in the cave have been recorded previously, either from the Gibraltar caves or from Mentone.

It has been remarked above that Cyprcea pyrum occurs at Cro-magnon and at Mentone in cave deposits. The shell Cassis sulcosa has been found at Les Eyzies ( $c f$. Evans in Rel. Aq., p. 179) and in the Mentone caves (cf. Rivière, op. cit., Pl. XIV).

The limpets and mussels occur in the greatest abundance, and were evidently the favourite or most easily procurable food of the inhabitants of the cave.

B. Echinodermata: Sphorechinus granularis.-This species is found at present in the vicinity of the Canary Islands. I have no note on its occurrence in caves or kitchen-middens.

\section{B. Summary and Conclusions.}

I will now attempt to summarise the results of the observations made in the course of the excavations described in the first part of this communication.

Regarding the Rock of Gibraltar as a field for future research into the early history of mankind, I am strongly impressed with the importance and the probable fertility of this source. I do not think the caves and other formations by any means exhausted, and I am confident that we have so far reaped but the firstfruits of an abundant harvest.

Passing from matters of opinion to those of fact, it is a pleasure to record the very keen interest now manifested in these matters by those on the spot, whether they be officers of the various Services of the Crown, members of the Civil 
Administration, or residents. At no previous epoch have circumstances been so favourable for the acquisition and preservation of such evidence as we seek.

The actual field of operations is three-fold at least, and possibly additional lines of work remain to be recognised and undertaken.

\section{The Bone-breccia of the great agglomerate of Buena Vista.}

Dealing with the literature, material, and observations at my disposal, I find first a series of problems connected with what may be termed the true "bonebreccia," as exemplified by that of Rosia, ${ }^{1}$ now so largely removed. This bonebreccia formed the matrix whence the fossil mammals described by Dr. Busk in 1879 (Transactions of the Zoological Society, vol. $\mathrm{x}$ ) were derived. It occupies fissures in the "great agglomerate" of Buena Vista. Dr. Busk has not assigned any human remains to contemporaneity with those animals. Nor have any human bones (discovered since that account was written) yet been associated with them. The animals constitute what may be termed the Pleistocene fauna of the Rock.

For various reasons, my own work on the spot has not been extensively directed to this breccia. ${ }^{2}$ In a survey such as this I am perhaps justified in adding a few more remarks on this matter. In regard to future research, the excavator will possess a great advantage denied to Dr. Busk at the time of writing, though not perhaps at the time of publishing his account in the Zoological Transactions. ${ }^{3}$ I refer to the report (so frequently mentioned in the descriptive part of this communication) on the geology of Gibraltar, by Professors Ramsay and Geikie. These authorities have produced a masterpiece of lucidity, which contributes enormously to a precise knowledge of the geological history of the Rock, and of its relation to its surroundings, including the African shore of the Straits. No conclusions will in future command attention should they neglect the geological evidence so clearly set forth in that report.

\section{Problems relating to Forbes' Quarry and its surroundings.}

We come now to the second division of the subject. This comprises the problems centred in Forbes' Quarry. In the foregoing pages I have explained that the interest is divided here between the "brecciated talus" and the cave (or caves still to be discovered) in relation thereto.

Taking the cave first, I can only repeat in the sense of my preliminary report that even at the risk of obtaining no animal remains, it was impossible to proceed until the characters of the cave-floor had been ascertained. This exploration has now been accomplished.

1 A corresponding bone-breccia was found in relation to fissures on Windmill Hill, and in the Genista Cave No. 1.

2 See, however, Appendix IV.

3 Dr. Busk published his paper in 1879 , but he must have worked on the material for years before the date of publication. The report of Professors Ramsay and Geikie appeared in 1878. 
The brecciated talus remains for consideration. We have seen that Dr. Busk referred the Forbes' Quarry skull to the superficial layers of this material. The reasons for specifying a superficial rather than a deeper zone are not given, save that the presence of sand on the specimen is mentioned. ${ }^{1}$ But sand occurs sparsely throughout the brecciated talus. Let us for a moment consider the nature of the latter.

This is an "agglomerate." But it is not identical with the "great agglomerate" of Buena Vista (which, we have seen, contains in fissures a bone-breccia with a Pleistocene fauna). Thanks to the report of Professors Ramsay and Geikie, a novice can now learn how these two varieties of agglomerate are distinguished from one another.

The agglomerate as seen at Forbes' Quarry is less dense than that of Buena Vista. So far as is known, it contains no fissures filled with bone-breccia of the type found at Rosia and in the lowest levels of the Genista caves. It has not been deeply submerged like the great agglomerate, although my discoveries of marine molluses help to confirm the view of its partial submergence, or that it was formed partly below water. But to all appearance submergence was not extensive, nor was it in time prolonged sufficiently to yield evidence of the consolidation and submarine erosion characteristic of the great agglomerate, but not found here.

It differs in regard to the substratum. The great agglomerate lies on shales (referred to the secondary period). But beneath the "later agglomerate," the next strata where visible are usually composed of sand with pebbles (the latter of limestone). Thus Professors Ramsay and Geikie described a shallow layer of sand with pebbles visible immediately below this later agglomerate at the "Prince's Lines." This is close to Forbes' Quarry, but nearly 100 teet higher above the sea.

Nevertheless the geologists surmise that similar relations and material will be found at the "King's Lines," which are adjacent to Forbes' Quarry and nearly upon the same level.

So far as Forbes' Quarry is concerned, I can adduce from my own observations only the sand-zones in the floor of the cave. These were admittedly non-fossiliferous, or practically so. Yet their small extent (although consolidation due to stalagmite formation in the cave made their exposure quite disproportionately difficult) goes far to discount any conclusion based upon this defect.

The inportance of discussing the substratum of the brecciated talus or later agglomerate depends upon the fact that Professors Ramsay and Geikie detected marnmalian bones in the sandy layer they describe in that position at the Prince's Lines. But the nature of those mammals has never been revealed. Here is a problem awaiting and inviting an immediate attack. In future investigations of the brecciated talus at Forbes' Quarry, I believe the proper plan of campaign would be to expose the substratum. If, as the geologists forecast, the sand is present as a distinct, even though shallow layer, it may contain mammalian bones here as at

${ }^{1}$ Cf. also Sera, op. cit., Archivio, etc.. vol. xxxix, 1909, pp. 15, 16. 
the Prince's Lines. It will not be forgotten that the Forbes' Quarry skull was encrusted with sand. Even a shallow zone of sand provides better chances for the preservation of fossil bones intact than do the innumerable angular fragments of which the brecciated talus is composed.

But I would add that the exposure of this underlying sandy stratum may involve work outside the Quarry altogether, and (if possible) at the back of the adjoining buildings which face N.E. on the Devil's Tower Road.

Similar considerations render it expedient that a watch should be kept on the progress of the work of removing the sand and gravel immediately to the east of these buildings ( $c f$. p. 3ă4) and on any operations near the King's Lines.

\section{The more recent cave-deposits of the Rock.}

The last subdivision of the subject comprises the caves and their contents so far as these are related to period subsequent to the disappearance of the Pleistocene fauna. At present, the human remains are referable with certainty to this and to no earlier period in the history of the Rock.

The contents of the second cave explored by me have reference to this period. The material, as explained in the descriptive portion of this paper, falls naturally into three subdivisions.

Of these, the first includes such traces of human activity as pottery and stone implements. The characters of these objects indicate that during the whole period of occupation by human beings the state of culture was at a lowly level. The earthenware is distinctly Neolithic in its relations, and indeed of an early type. The implements cannot be justifiably separated from the pottery, even though some are of Mousterian, i.e., of Palæolithic type. The ornaments, too, are of the simplest description, viz., the perforated Cypræa, and the shell anklet described above. ${ }^{1}$ The total absence of polished implements and of any trace of metal is important. Polished implements and metal objects occurred in the Genista caves. The inference is that the prehistoric inhabitants of the Rock in other but adjoining habitations, passed to a higher stage of cultured evolution than those whose handiwork we are now considering. In view of the inaccessibility of Cave S, it may well have been abandoned early in the Neolithic age, perhaps after the death of an occupant. This is merely a surmise, but I may add that, taken as a whole the general aspect recalls that of the earlier settlements at Cro-magnon, as depicted in the graphic pages of the Reliquice Aquitanico. But we have part only, not the whole of that picture. But then we have literally not got to the bottom of the matter, for my excavations, though extending to the depth of a metre and a half in the deepest part of the cave-earth, failed to attain the bed-rock. It is by no means improbable that deep in the corner marked $A$ on the plan (Fig. 1 in the text), still richer treasures await a more fortunate excavator.

1 A special search for artificially perforated phalanges of Ungulata, similar to those found at Les Eyzies, was unsuccessful. 
To the best of my judgment, the material of the artefacts appears to be local. Certainly the silicified sandstone and chert occur on the Rock, sparingly no doubt, but still undoubtedly. An exception must be made in the case of the heavy block of hæmatite ore, but with this exception the objects reveal, as already mentioned, a settlement of human beings in the lowliest circumstances, comparable to those of the kitchen-middens.

We now come to the evidence of the human bones. It is inadvisable now-adays to lay stress upon the characters of an individual, yet in this case the lines of evidence are so convergent that a few remarks seem justifiable. The evidence is provided by the fibula, the astragalus and the tibia. Of the first two bones, each bears a character found with unwonted frequency in Neolithic skeletons as contrasted with its rarity in those of modern Europeans.

The tibia provides no less than three perfectly definite characters distinguishing it from the normal type of the modern bone. They associate it with Neolithic tibiæ, and the tibiæ of such of the existing human races as are capable of habitually adopting the attitude of "squatting:" I may note that of these characters, one only (platycnemia) has been remarked before in the cave-bones of the Rock. A second (retroversion of the tibiæ head) is present in a high degree. The third has been less studied in the history of cave-exploration so that a word may be added on this subject "here. The character in question is the upvard extension of the inferior articular surface of the tibia, forming an upwardly directed lappet or facet of articular area on the front of the lower part of the tibiæ shaft. The Spy and Cro-magnon tibiæ lack this facet, but other Neolithic tibiæ possess it with great constancy.

In Crete I obtained six tibiæ from a Neolithic cave-shelter at Agios Nikolaos (Sitia). All these tibiæ possess the facet in question.

Such evidence makes strongly in favour of assigning the human bones from Cave $\mathrm{S}$ to the Neolithic period; in fact, to that denoted by the pottery. As regards other circumstances in connection with the human bones, I think the evidence on the whole runs against a theory of deliberate interment. The condition of dispersion in which the bones were found is antagonistic to such a view. That the individual lost his life through the fall of a massive block from the cave-roof is by no means unlikely. Our failure to find the least trace of the cranium might be explained if that part of the body had been crushed at the time of death. The dispersion of the various parts still remains obscure, and one is perforce thrown back on an appeal to the action of wild animals in this connection. It must be admitted that the human bones are singularly devoid of traces of gnawing; and herein present a marked contrast with the remains of goats.

Lastly we come to the associated fauna. Certain factors have to be taken into consideration here. The presence of raptorial birds will account for a proportion of the remaining animals. To the credit of these winged carnivora must be placed most of the bones of smaller birds, the majority of the rabbits and some of the young goats, with a few at least of the small rodents. The mollusca and echinus, 
a large proportion of the goats and probably the seals ${ }^{1}$ owe their presence (in a cave 800 feet above the sea) to human agency.

The extraordinary confusion of the remains has been noted already. On this account I regard the accumulation as a sort of cave kitchen-midden. Turning to the significance of the list of animals of all kinds actually represented, there is but little to add. The fauna is the prehistoric one, and while I have been able to add some new names to the earlier lists, the character of these has not been materially altered. I was careful to sift this evidence with all the care at my disposal, on the general ground that some significant form may be represented by a single bone, and this may indeed be the case with the chamois, and certainly is so with the tortoise and (?) monitur. But a more particular reason was that Major Sewell tells me that, some years ago, remains of an "Arctic rodent" were discovered in a neighbouring cave. This may have been "Holyboy's Cave" not far distant from Cave S.2 With especial care, therefore, I worked through dozens of small bones obtained from an extensive pocket near A ( $c f$. Plan, Fig. 1 in the text). I am fairly confident that I have overlooked nothing distinctive of any auimal capable of being so described, and the record of such a form remains still to be published. I may remark that Dr. Gadow has recorded the presence of the lemming in the caves of Portugal.

In concluding this Report I wish once more to tender my thanks to those who helped iny work in various ways, and to express the hope that the University of Cambridge may be able to provide for further researches of this kind.

\section{APPENDIX I.}

In the prosecution of the researches described in this communication, I received much help from those whose names are here appended. My best thanks are due to all for their co-operation.

H.E. The Acting Governor, General Perrott, C.B.

Rear-Admiral F. S. Pelham.

Superintending Civil Engineer, E. Wakeford, Esq., M.I.C.E.

1 The scarcity of the remains of the seal in prehistoric deposits of all periods is very striking and deserves special investigation.

2 From Holyboy's Cave I obtained bones of the rabbit, rock-dove and a tbrush-like bird. I may add that though the further information was given to me that the discovery of the Arctic rodent was communicated to the Zoological Society, the Proceedings of that body since about 1890 seem to contain no such record. I searched the zoological record from 1899 onwards, but without discovering any reference of the kind. The whole subject of the significance of bones attributed to Myodes (lemming), and their value as indicative of Arctic conditions requires re-investigation. This is imperatively necessitated by the statements of BarrettHamilton (Proceedings of the Zoological Society, 1896, pp. 306 et seq.), who suggests that a variety of lemming may be found still existing in Spain. The exact nature of the small rodent found in the Sierra de Gredos, and called locally the "Liron," should be specially ascertained. 
Deputy Expense Accounts Officer, F. W. Cary, Esq.

Deputy Ordnance Store Officer, G. A. Storey, Esq.

Major A. W. Abercromby, G.S.O.

Colonel E. R. Kenyon, R.E.

Major G. P. Scholfield, R.E.

Lieut. R. K. A. Macaulay, R.E.

Major Sewell, R.E.

W. Turner, Esq., M.V.O., M.A., M.D., Surgeon to the Colonial Hospital.

B. H. T. Frere, Esq., LL.B., Attorney-General.

J. Rowland Crook, Esq., A.M.I.C.E.

W. Wallace Copland, Esq., A.M.I.C.E., F.R.M.S.

Mr. Sweeny.

Mr. Ferrari.

\section{Appendix II. \\ Report on the Collections Exhibited at the Garrison \\ Library, Gibraltar.}

These collections are stored in a room adjoining the Garrison Library. They fill three large cases with glass doors. These cases will be referred to as Nos. 1, 2, and 3, numbered from the south end of the room, Case No. 1 being the furthest from the doorway.

\section{Case No. 1.}

This contains trays with specimens from Collins' Cave. The precise situation of this cave is about 420 feet above sea-level. It lies due west of the northern portion of Catalan Bay village.

The specimens are divisible into two series. Of these, one comprises bones very similar in appearance to those found by me in Cave $\mathrm{S}$, and described in my Report. From Collins' Cave the human remains are not very numerous, consisting principally of metatarsal bones. The associated fauna includes the ibex, boar, rabbit, ox, and deer (described as $C$. elephas). The femur ascribed to a "large cat" is probably that of a lynx. Birds are represented by the humerus of an eagle or vulture. With these bones there is a certain amount of gritty (? siliceous) sand which I cannot match with any of the soil from Cave S.

In addition to the foregoing objects, Collins' Cave provided another series of remains. These consist of three or four blocks of red brecciated earth containing bones which I could not identify. Their general condition resembles that of bones found by me at Pikermi in Attica, and is strongly contrasted with that of the other bones from Collins' Cave. They are described as having been derived from the deeper levels of the cave. 


\section{Case No.2.}

This contains many trays of bones from the Genista Caves, Nos. 2 and 3 ( $c f$. Busk, op. cit., 1868, for reference to these caves). There are also five human metatarsal bones from Collins' Cave. Lastly, we find masses of red breccia with fragments of large bones referred (though the authority is not given) to Elephas antiquus.

On the human remains from the Genista caves (Nos. 2 and 3) I made the following notes :-

Skulls are represented by parts of the upper maxilla and the mandible of an adult woman. There is part of a male maxilla. The female bones are small, the upper maxilla showing no marked prognathism. The mandible has a somewhat large angle $\left(120^{\circ}\right)$ and the chin is not very prominent. A feature of distinction seemed at first to be present in the narrowness of the space between the two rami. But the length-breadth index is 121 , so that no inferiority is really denoted. 'The most marked degree of this narrowing I have seen is exhibited by the mandible of a South African Bush woman, in which the corresponding index is 84:3 (Mus. Anat. Cant., Specimen B).

A male temporal bone (right side) has a small mastoid process, exposing part of the digastric groove, but no great stress can be laid upon this character, as here developed.

Of associated bones, but one collection is to be found. This comprises a female pelvis with a well-curved sacrum, both humeri, left radius and right femur. The latter is undoubtedly female, though the linea aspera is remarkably prominent, giving the characteristic "carinate" form already noted by Busk (op. cit., 1868) in the femora from the Genista caves. Indeed, for all that is known, that author may have based his description on this very bone.

In addition to the foregoing bones, two other sacra next claim attention. They differ entirely from the curved female sacrum just mentioned, in respect of their form, which is extraordinarily flattened. Otherwise both bones are rather small in comparison with modern European sacra.

Of other limb bones, six clavicles, part of a right scapula, three humeri, one ulna and one tibia remain for consideration.

The clavicles are distinctly slender, but they present a remarkable range of variation in respect of their curvature. In the humeri, the olecranon fossa is imperforate in each example. In the ulna, the olecranon process is well developed, exhibiting no feature of inferiority.

The tibia is not platycnemic: the lower end has been destroyed, so that no observation on the lower articular surface is possible.

\section{Case No. 3.}

This case contains numerous sherds, and also flint or chert implements from caves in the rock. There are a few miscellaneous osteological specimens, including 
three crania of the Gibraltar ape, showing well the several differences in the skulls of this species. Various mineralogical specimens and stalactites from the caves, together with certain relics of the Great Siege, complete the list of objects preserved here.

\section{Appendix III.}

\section{Masses of Breccia containing Bones.}

A room in the Garrison Library at Gibraltar contains several hundredweights of blocks of stalagmite, varying in size from that of an orange to that of a football. Most of these blocks contain fragments of bones. They were obtained in the course of excavating a magazine in one of the Genista caves (No. 1) on Windmill Hill Flats in the years 1895-96. The actual locality was a small cave, twenty-five feet deep, and beneath the present "shifting and examining" rooms. This small cave has no connection with the larger caves existing beneath the magazine. The foregoing information was kindly supplied by Colonel Kenyon, R.E. (cf. Correspondence, 1910, in the Gibraltar Garrison Library Records).

In regard to the animals represented by these bones, I have been able to recognise with certainty bones of Ungulata only. There are portions of limb-bones of Rhinoceros, Bos, and Cervus. In some instances, splinters of bone have become detached from the matrix and can thus be examined more thoroughly. I have been unable to detect any remains of Carnivora.

The substance of this report (on these fragments) was communicated to Colonel Kenyon, before my departure from Gibraltar, in October, 1910.

\section{APPENDIX IV.}

Since the foregoing Report was written, I have received news of a great landslip which took place on Christmas Day, 1910. Early on that day an immense fall of rock occurred, hundreds of tons being precipitated into Forbes' Quarry, which was thereby filled up almost entirely. The mouth of the cave has thus been rendered practically inaccessible. Inasmuch as the fallen masses are derived from what was previously solid rock in the heights above, no important exposure has been made thereby. But the incident provides an admirable example of the mode of formation of the brecciated talus.

\section{List of Illustrations with Legends to Figures.}

\section{Plate XL.}

Fig. 1. Sketch of Forbes' Quarry, Giluraltar, with cave. This part of the quarry is now (February, 1911) filled up completely with the débris from the landslip of December 25, 1910. 
Fig. 2. From the brecciated talus adjoining Forbes' Quarry :-

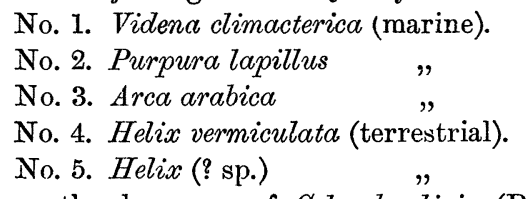

The other specimens are the humerus of Columba livia (Rock dove), and part of the humerus of Capra hircus (Goat).

Fig. 3. Purpura homastoma from Cave S. Three curiously perforated examples.

Fig. 4.-No. 1. Cyprcea pyrum artificially perforated, from Cave S.

No. 2. Delicate flint lamina fronı Cave S.

No. 3. Part of an armlet or anklet of shell (? Triton) from Cave S.

Fig. 5. As in Fig. 4, showing opposite side of anklet from Cave $\mathbf{S}$.

Fig. 6. Fauna of Cave S :-

Nos. 1 and 2. Trochus tessellatus.

Nos. 3 and 4. Purpura homastoma.

No. 5. Purpura (? species).

The remaining specimen is Solen vagina.

\section{Plate Xli.}

Fig. 1. Stone implements and hæmatite block (No. 11) from Cave S. No. 2 is a typical Mousterian implement of quartzite.

Fig. 2. Stone implements of Mousterian type from Cave S. The specimens are Nos. 7, 13 and 15 (cf. text).

Fig. 3. Stone cores (Nos. 1 and 12) and hammerstone (No. 10) from Cave S.

Fig. 4. Fauna of Cave $S$ :-

No. 1. Humerus of Testudo grocea.

No. 2. Humerus of bat (? Pipistrellus.)

Nos. 3 and 4. Recent terrestrial Helix.

(Species not identitied.)

No. 5. Mandible of Mus sylvaticus lewisi.

No. 6. Mandible of Mus sp. ? rattus.

No. 7. Mandible of Sorex araneus? granarius.

No. 8. Os innominatum : Arvicola (? species).

Fig. 5. Distal aspects of entocuneiform bones. The largest (to the left) is from the skeleton in Cave $\mathbf{S}$; the central one is from the skeleton of an aboriginal native of Australia (Mus. Anat. Cant.) ; the remaining (smallest) bone is from the skeleton of an adult chimpanzee (Mus. Anat. Cant.).

Fig. 6. No. 1. Stalagmite mass from the floor of the cave in Forbes' Quarry.

No. 2. Stalagmite mass containing a land molluse (H. vermiculata), at a depth of 3 feet 6 inches from the surface. From the floor of the cave in Forbes' Quarry.

Fig. 7. Stone implements and chips from Cave S.

\section{Plate XLII.}

Fig. 1. Two views of the right astragalus from Cave S. A is the abnormal facet noted in connection with a similar tacet on the tibia (cf. Fig. 4).

Fig. 2. Sections of tibia at level of junction of the soleal ridge with the internal border, to show platycnemia. D is a modern specimen from the Cambridge Anatomy School ; C R is the Cro-magnon tibia ; G I B is the right tibia from Cave $S$.

Fig. 3. Two tracings of right human tibia from Cave $\mathrm{S}$ to show retroversion of the head of this bone (angle $16^{\circ} 15^{\prime}$ ).

Fig. 4. Front and back views of the right tibia from Cave S. Cf. note on Fig. 1 supra. 


\section{Plate XLIII.}

Fig. 1. Front views of Cro-magnon tibia (above) and tibia from Cave $\mathbf{S}$ (below).

Fig. 2. Tibiæ from Cave $S$ (the two bones to the right) compared with the cast of a tibia from Cro-magnon.

Fig. 3. Remains of adult male human skeleton from Cave S.

Fig. 4. Fauna of Cave S. Radius and humerus of goat and ibex, the latter being the larger specimens.

Fig. 5. Fauna of Cave S. No. 1. Metatarsal bone of Chamois. The remaining bones are as follows: Goat, fractured metatarsal bone and fractured femur. Ibex : femur (complete). 
Journal of the Royal Anthropological Institute, Vol. XLI, 1911, Plate XL.

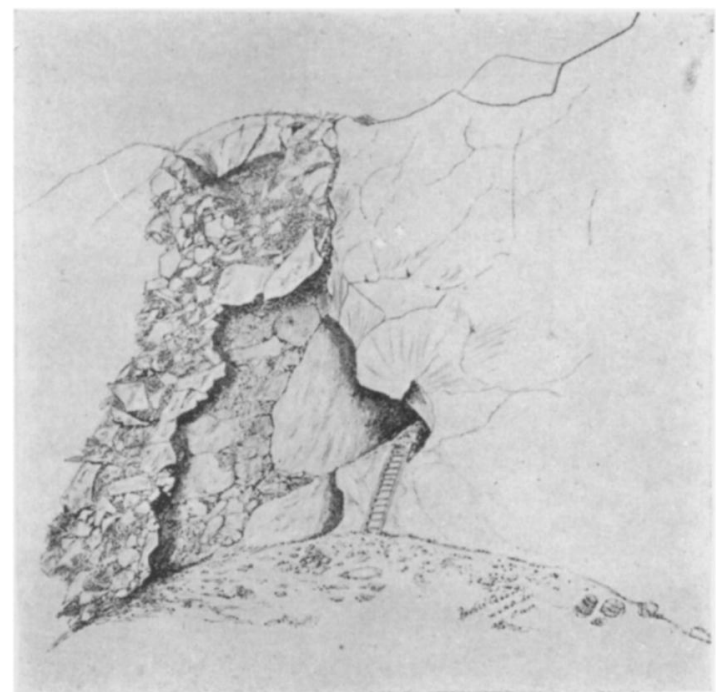

FIG. 1.

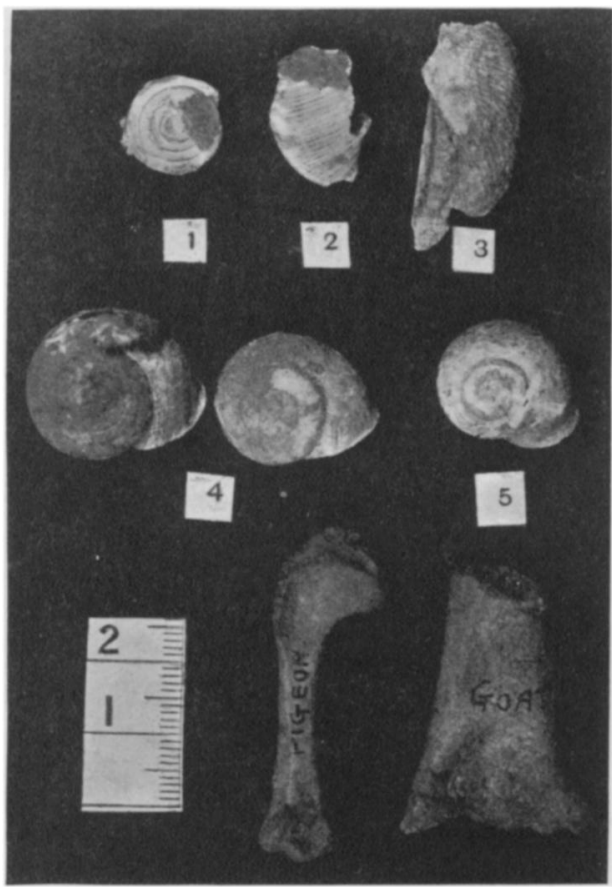

FIG. 2.

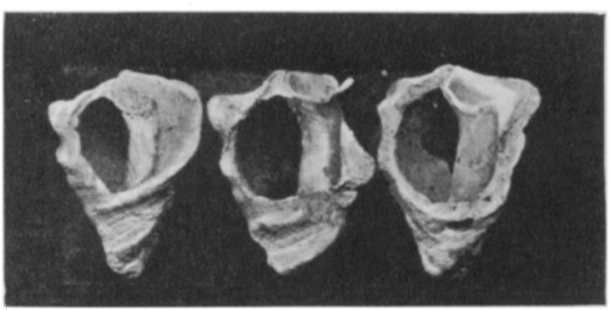

FIG. 3.

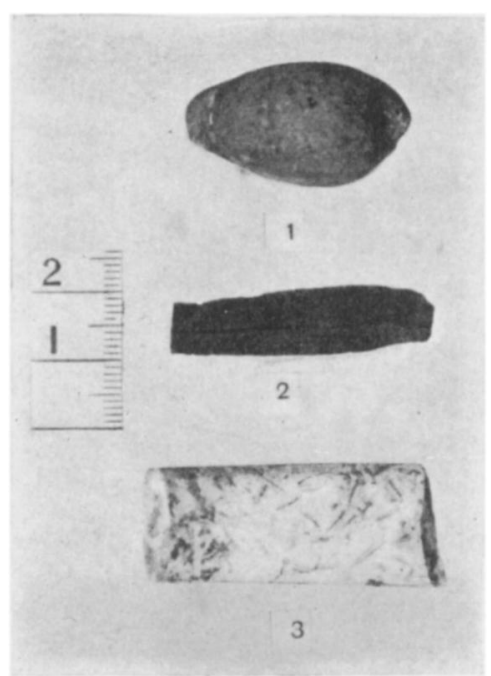

FIG. 4.

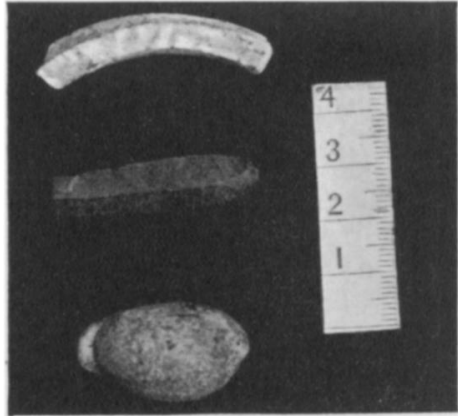

FIG. 5 .

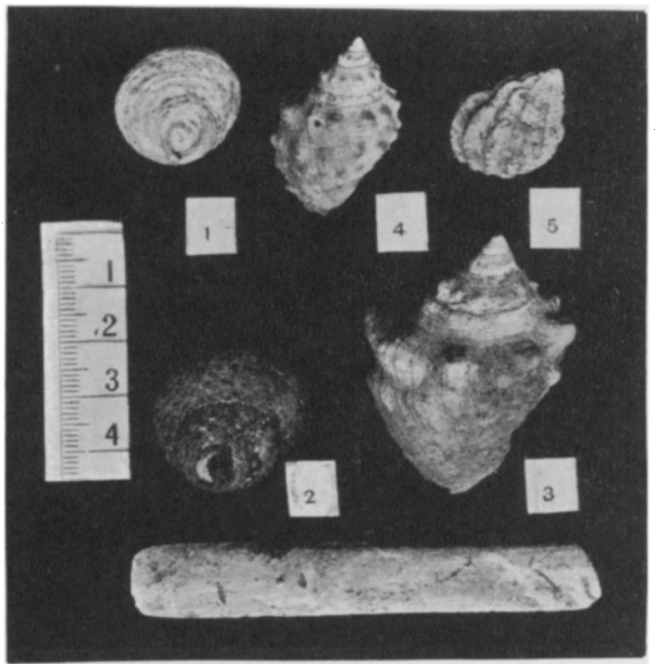

FIG. 6.

CAVE EXPLORATION AT GIBRALTAR IN SEP'TEMBER, 1910.

This content downloaded from 141.233.160.21 on Thu, 07 Jan 2016 16:35:34 UTC All use subject to JSTOR Terms and Conditions 


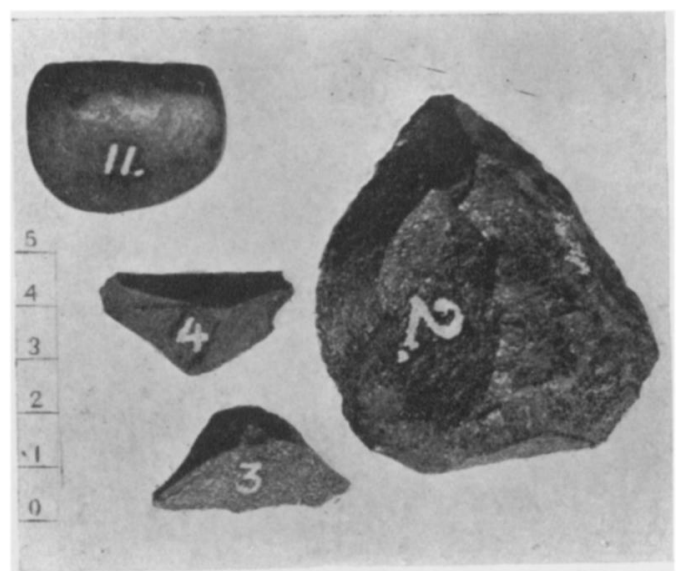

FIG. 1.

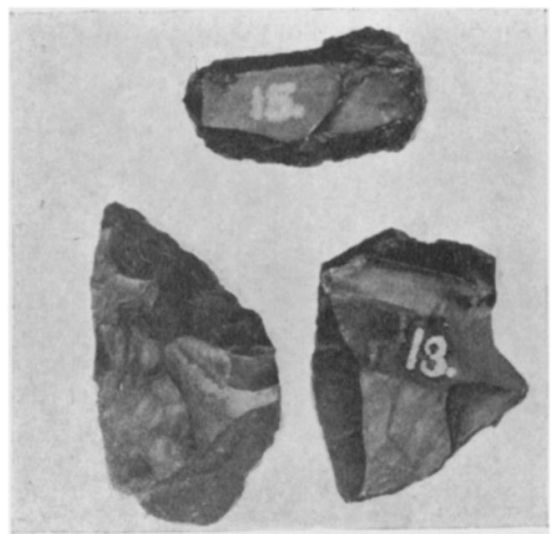

FIG. 2.

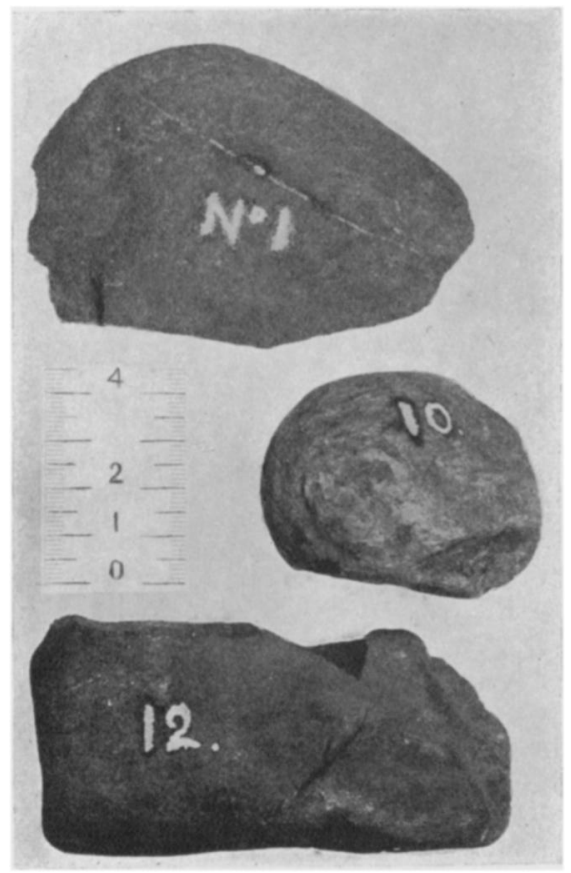

FIG. 3.

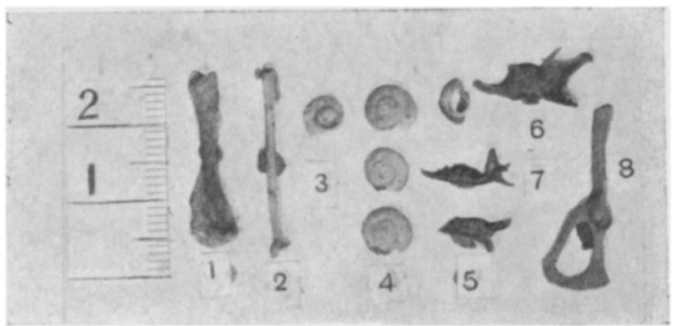

FIG. 4.
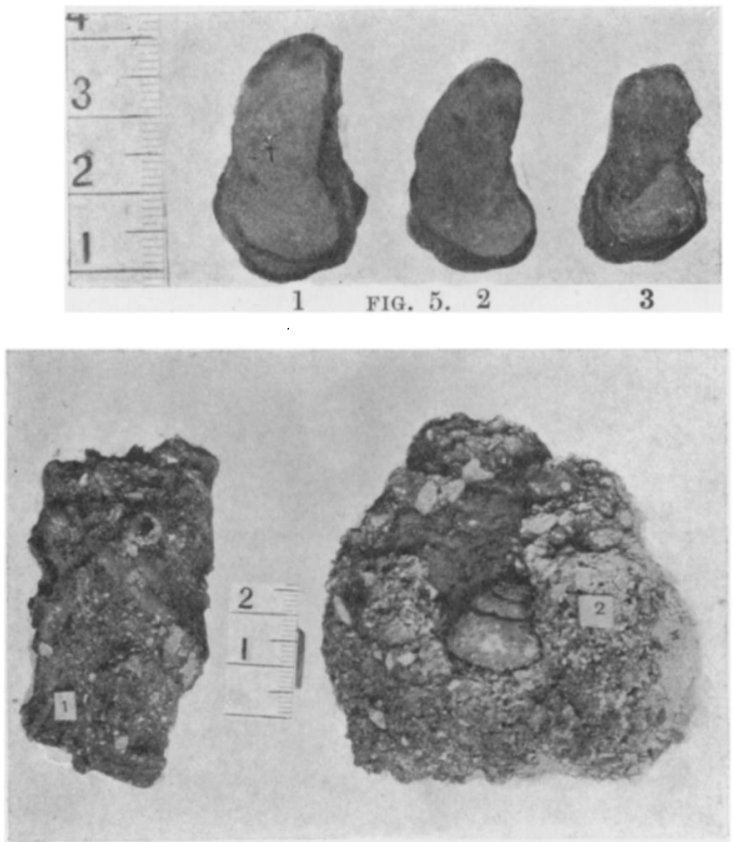

FIG. 6 .

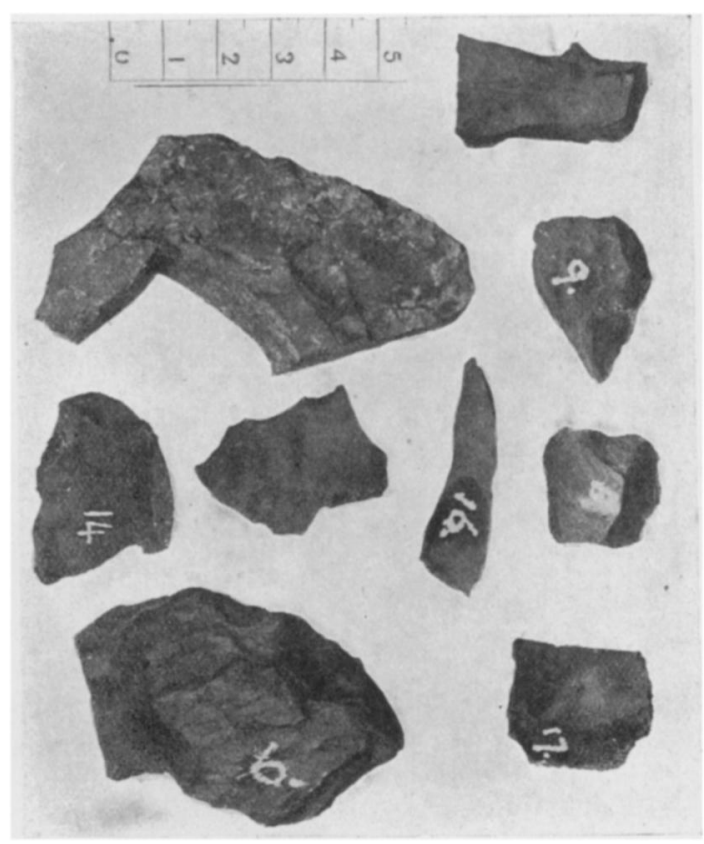

FIG. 7 .

CAVE EXPLORATION AT GIBRALTAR IN SEPTEMBER, 1910. 
Journal of the Royal Anthropological Institute, Vol. XLI, 1911, Plate XLII.

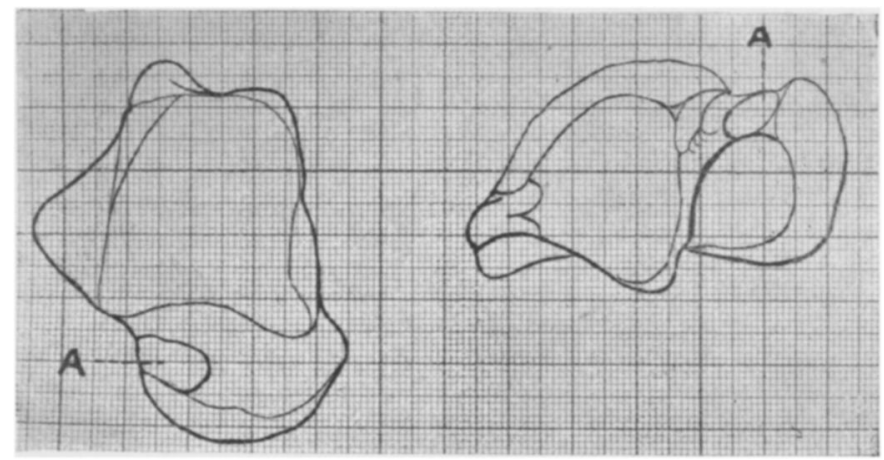

FIG. 1,
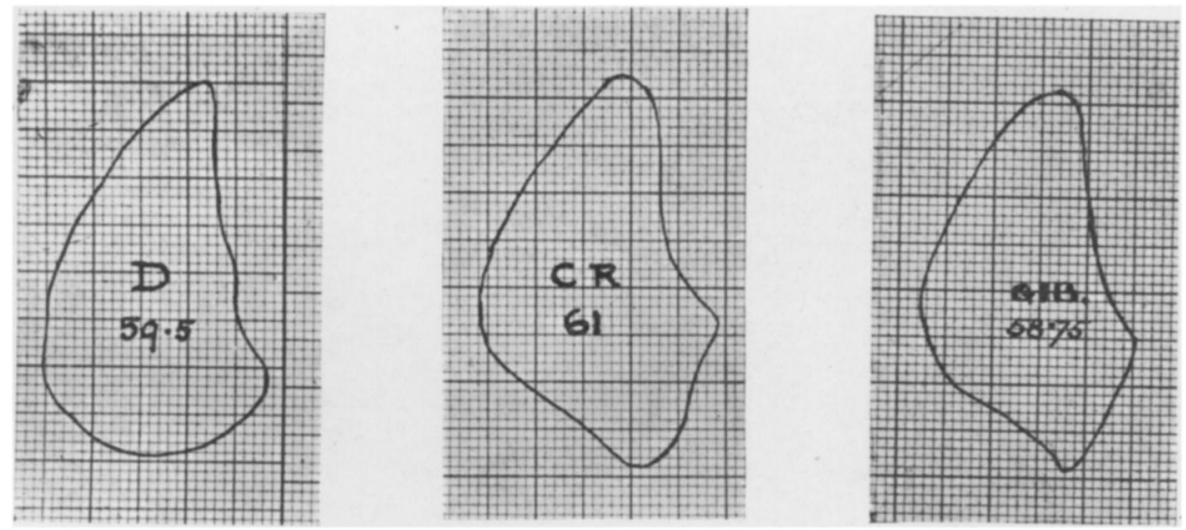

FIG. 2.

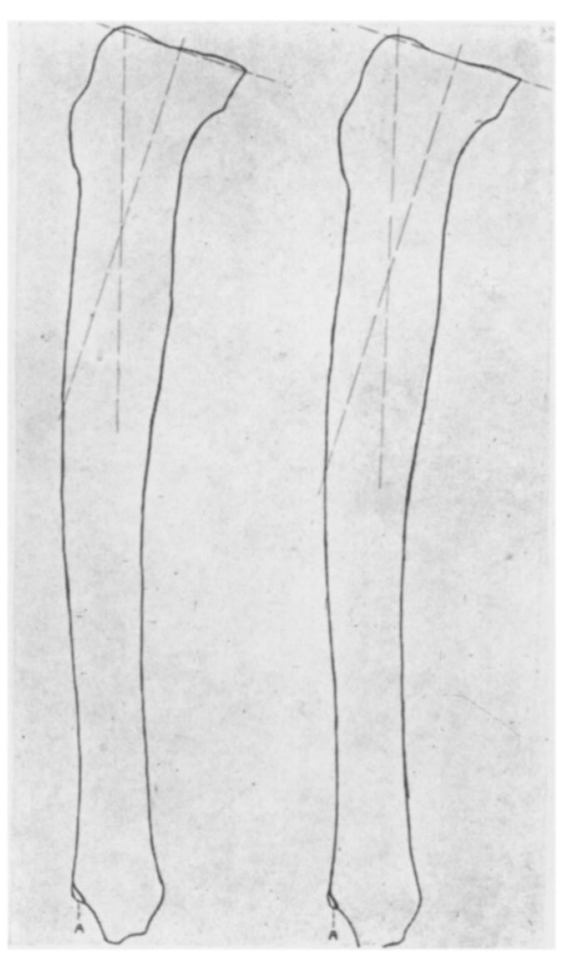

FIG. 3.

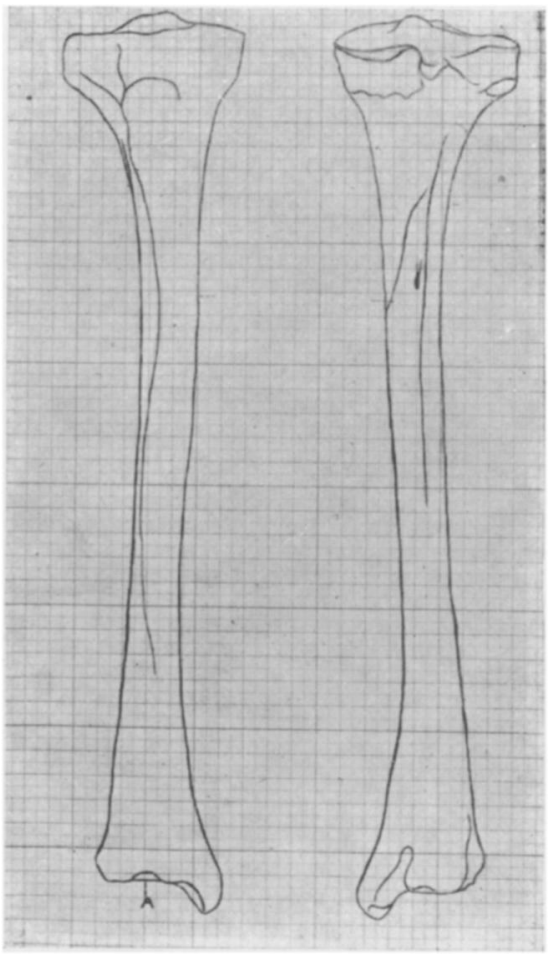

FIG. 4.

CAVE EXPLORATION AT GIBRALTAR IN SEPTEMBER, 1910.

This content downloaded from 141.233.160.21 on Thu, 07 Jan 2016 16:35:34 UTC All use subject to JSTOR Terms and Conditions 
Journal of the Royal Anthropological Institute, Vol. XLI, 1911, Plate XL1II.

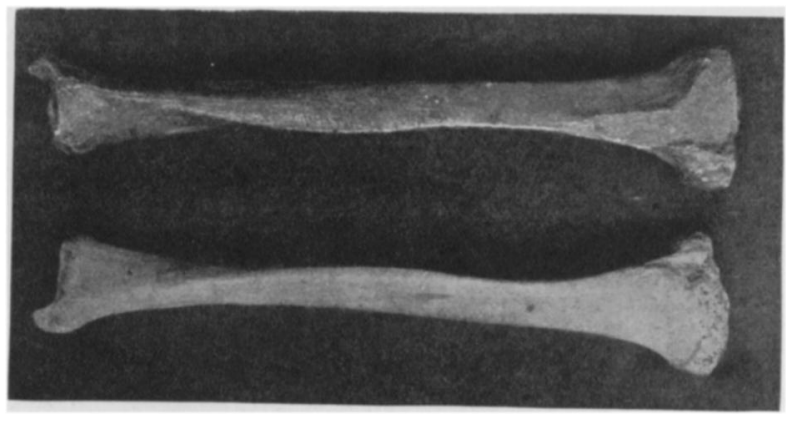

FIG. 1.

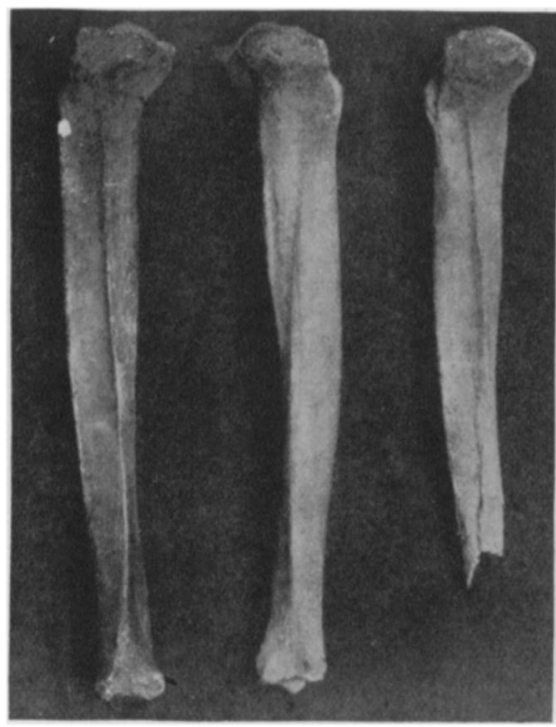

FIG. 2 .

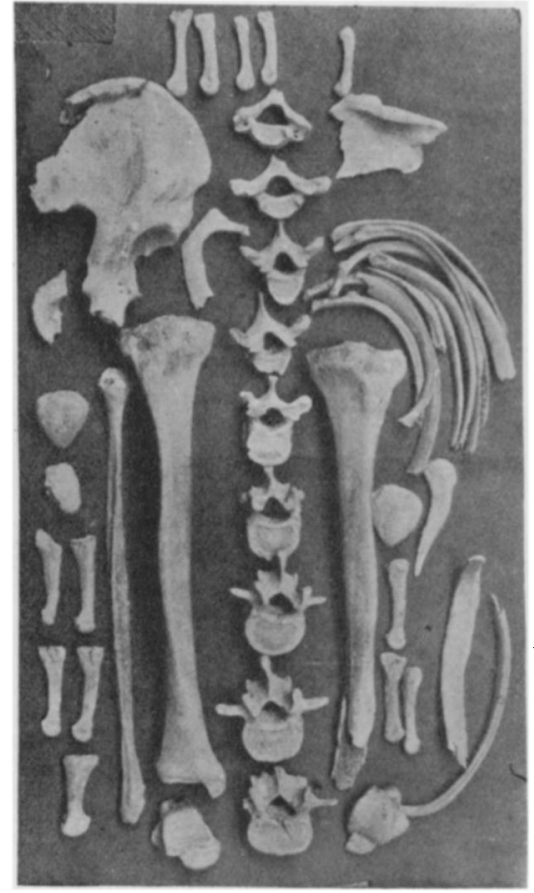

FIG. 3.

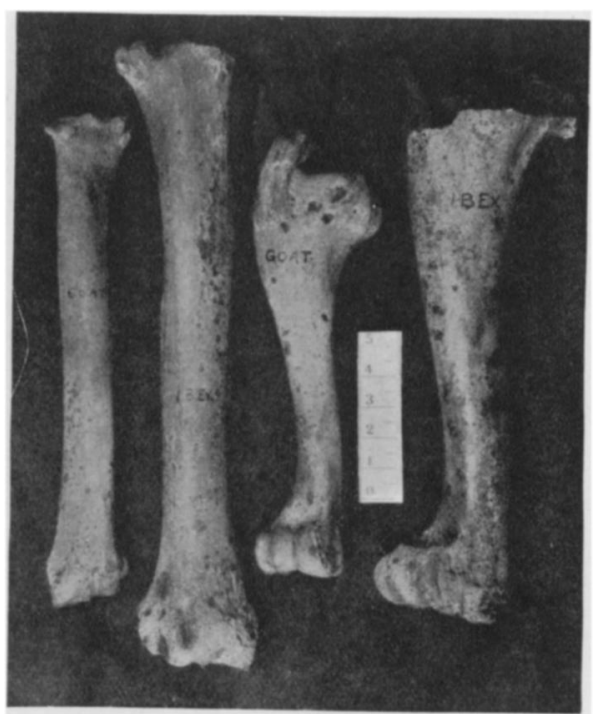

FIG. 4.

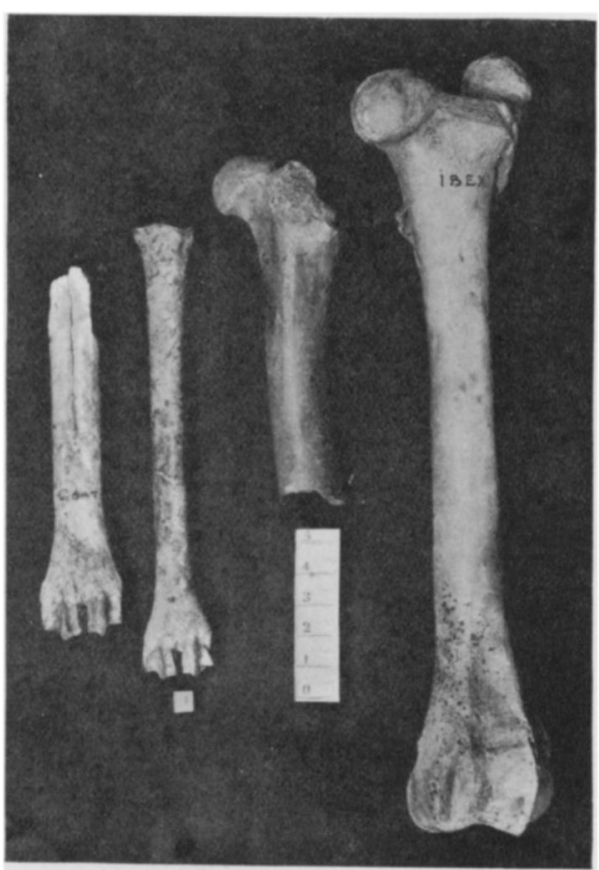

FIG. 5 .

CAVE EXPLORATION AT GIBRALTAR IN SEPTEMBER, 1910. 